\title{
Tatiana KRYNICKA*
}

\section{STAROTESTAMENTALNE CUDA W POEMACIE PASCHALE CARMEN SEDULIUSZA}

Prezbiter i chrześcijański poeta łaciński Seduliusz Celiusz żył w 1. poł. V wieku ${ }^{1}$. Całość znanego nam dorobku Seduliusza ma charakter religijny. Składają się nań: dwa hymny, epicki poemat Paschale carmen ${ }^{2}$ oraz jego prozaiczna adaptacja zatytułowana Paschale opus. Seduliusz jest jednym z najwybitniejszych wczesnochrześcijańskich epików obok Juwenkusa, Awita, Aratora i Drakoncjusza. Spośród nich wszystkich jest on ponadto autorem najlepiej znanym czytelnikowi polskiemu dzięki szeregowi prac, które poświęcili mu w różnym czasie Bronisław Hieronim Gładysz ${ }^{3}$ oraz Henryk Wójtowicz ${ }^{4}$. Ten ostatni pozostawił też wspaniały przekład wszystkich dzieł poety, który ukazał się nakładem Towarzystwa Naukowego KUL w Lublinie w 1999 roku $^{5}$.

Najważniejszy i najbardziej znany utwór Seduliusza to niewątpliwie $P o-$ emat paschalny ${ }^{6}$, oparty w głównej mierze na Ewangelii według św. Mateusza ${ }^{7}$ i traktowany przez badaczy przede wszystkim jako epos nowotestamentalny ${ }^{8}$.

* Dr Tatiana Krynicka - adiunkt w Katedrze Filologii Klasycznej na Wydziale Filologicznym Uniwersytetu Gdańskiego; e-mail: tatianatko@yahoo.es.

${ }^{1}$ Zdania uczonych co do jego pochodzenia i miejsca zamieszkania są bardzo podzielone. Nie wiemy, czy był on z pochodzenia Galijczykiem, Hiszpanem, czy mieszkającym w Rzymie Italczykiem. Przebieg życia i losy poety omawiają: SWP 352-353; M. Cytowska - H. Szelest, Literatura rzymska. Okres cesarstwa. Autorzy chrześcijańscy, Warszawa 1994, 310-312.

${ }^{2}$ Poemat analizuję na podstawie wydania: Sedulius Caelius, Opera omnia. Dzieła wszystkie. Tekst tacińsko-polski, tłum. i oprac. H. Wójtowicz, Lublin 1999, 86-221. Łaciński tekst utworów Seduliusza w tym wydaniu został przytoczony za wydaniem J. Huemera (CSEL 10, Vindobonae 1885, 1-154).

${ }^{3}$ Por. B. Gładysz, Dogmatyczne teksty w poetyckich utworach Seduliusza. Studium z historii dogmatów V wieku, Poznań 1930; tenże, De extremis quibus Seduliana carmina ornantur verborum syllabis inter se consonantibus, Leopoli 1930; tenże, Abecedariusz Seduliusza, „Kurjer Poznański” (1936) 594. Niestety nie miałam dostępu do tych pozycji w czasie pracy nad artykułem.

${ }^{4}$ Wykaz poświęconych Seduliuszowi prac H. Wójtowicza czytelnik znajdzie w sporządzonej przez niego bibliografii, która została zamieszczona w wydaniu dzieł poety (Bibliografia, w: Sedulius Caelius, Opera omnia, s. 67-68); ponadto por. tenże, Inwokacja w „Paschale carmen”, w: Christianitas et cultura Europae. Księga jubileuszowa profesora J. Kłoczowskiego, red. H. Gapski, cz. 1, Lublin 1998, 30-39; tenże, Alegoreza w „Paschale carmen” Seduliusza, RH 48 (2000) z. 3, 93-109.

${ }^{5}$ Pełny opis bibliograficzny wydania por. nota 2.

${ }^{6}$ Por. H. Wójtowicz, Wstęp, w: Sedulius Caelius, Opera omnia, s. 10.

${ }^{7}$ Por. Cytowska - Szelest, Literatura rzymska, s. 310.

${ }^{8}$ Por. R. Green, Latin Epics of the New Testament. Juvencus, Sedulius, Arator, Oxford 2006, passim. 
Tymczasem, moim zdaniem, na uwagę zasługują również obecne w Paschale carmen wzmianki o wydarzeniach, które miały miejsce przed przyjściem Mesjasza na świat.

Przekazując czytelnikowi Paschale carmen, Seduliusz oznajmia, iż zamierza przedstawić w poemacie wspaniałe cuda Chrystusa Zbawcy: clara salutiferi [...] miracula Christi ${ }^{9}$. Poeta wyznaje, iż rozsławianie całym umysłem i sercem Najwyższego, który obdarzył każdą ludzką istotę umysłem i sercem, sprawia mu ogromną rozkosz ${ }^{10}$. Syn Boży jest jedynym godnym chwały Panem wszechświata, równym Ojcu pod względem sprawowanej władzy, wspaniałości, potęgi i chwały; jest też wieczny jak Ojciec. Wyznawanie tej nauki stanowi, zdaniem poety, pewną drogę zbawienia dla ludzkości (via [...] saluti $^{11}{ }^{11}$, wyczekującej od czasu tragicznego upadku prarodziców na przyjście obiecanego Mesjasza ${ }^{12}$, który swoją krwią, niczym wspaniałym antidotum, udaremni moc trucizny węża z ogrodu Eden ${ }^{13}$.

Zbijając poglądy Ariusza i Sabeliusza, Seduliusz z mocą podkreśla, iż wszystkie trzy Osoby Trójcy tworzą doskonałą jedność. Posługuje się przy tym zasługującymi na uwagę paradoksami, a mianowicie mówi, iż jedna odwieczna postać bóstwa potraja to, co niezłożone, a zmienia w jedność to, co trojakie ${ }^{14}$. Trzy Osoby Boskie są całkowicie zgodne w działaniu. Sprawcą będących w centrum uwagi autora poematu cudów nowotestamentalnych jest Chrystus, który dokonuje ich wspólną mocą z Ojcem oraz przy zgodnym współdziałaniu Ducha. Jednak cudownych boskich ingerencji ludzie doświadczali również w czasach Starego Testamentu. Sprawcą starotestamentalnych cudów był działający w tejże doskonałej łączności z Synem i Duchem Bóg Ojciec. Zauważmy, iż mówiąc o cudach Nowego i Starego Przymierza, tych

${ }^{9}$ Sedulius, Paschale carmen I 26, Wójtowicz, s. 88.

${ }^{10}$ Por. tamże I 27-29, Wójtowicz, s. 88: „Dominumque tonantem / Sensibus et toto delectet cordo fateri / Qui sensus et corda dedit".

${ }^{11}$ Tamże I 25, Wójtowicz, s. 88; por. tamże I 29-36, Wójtowicz, s. 88. H. Wójtowicz (Grzech pierworodny w twórczości Seduliusza, VoxP 17 (1997) t. 32-33, 278) odnosi do Chrystusa wypowiedź poety o drodze zbawienia.

${ }^{12}$ W ks. I i II poematu Seduliusz (Paschale carmen I 60-78, Wójtowicz, s. 90-92; II 1-34, Wójtowicz, s. 118-120) pokrótce przedstawia wydarzenia, które poprzedziły przyjście Mesjasza: od stworzenia świata, poprzez upadek pierwszych ludzi, powołanie Abrahama i kolejne wieki dziejów narodu wybranego; por. Wójtowicz, Wstęp, s. 14-15. Wypowiedzi poety dotyczące upadku prarodziców analizuje H. Wójtowicz (Grzech pierworodny w twórczości Seduliusza, s. 282-289), który widzi w Seduliuszu znakomitego świadka nauki 1. poł. V w. o grzechu pierworodnym.

${ }^{13}$ Por. Sedulius, Paschale carmen I 71-72, Wójtowicz, s. 92: ,potuque sacrati / Sanguinis infusum depellis ab angue venenum". Na ukąszenia węży i skorpionów stosowano różnorodne okłady i napoje (m.in. rosół z gęsi, owcy, cielęcia, nierozcieńczone wino z pieprzem, winny ocet, sok z porów). Płyny te działały jako moczopędne i wymiotne środki, pomagając organizmowi uwolnić się od trucizny. Szczegółowo pisze o tym Celsus (Aulus Cornelius Celsus, De medicina libri octo V 27, 3-10, ed. C. Daremberg, Lipsiae 1859, 253-256).

${ }^{14}$ Por. Sedulius, Paschale carmen I 297-298, Wójtowicz, s. 110: „Semper ut una manens deitatis forma perennis / Quod simplex triplicet quodque est triplicabile simplet”. 
dokonywanych przez Chrystusa (sancti coniuncto Spiritus actu / Quae Natus socia Patris virtute peregit ${ }^{15}$ ) oraz przez Ojca (sancti coniuncto Spiritus actu / Quae Genitor socia Nati virtute peregit ${ }^{16}$ ), Seduliusz posługuje się właściwie identycznym słownictwem.

Opis zbawczych Bożych interwencji w starotestamentalne dzieje ludzkości znajdujemy w pierwszej księdze poematu, mającej charakter wprowadzenia ${ }^{17}$. Seduliusz relacjonuje czytelnikowi osiemnaście niezwykłych wydarzeń, przy czym dwa $\mathrm{z}$ nich wiążą się $\mathrm{z}$ osobą Izaaka ${ }^{18}$, dwa $-\mathrm{z}$ prorokiem Eliaszem ${ }^{19}$; każde spośród pozostałych dotyczy jednej osoby lub grupy osób, która doświadczyła cudownego Bożego działania. Jak już niejednokrotnie zostało zauważone, komponując Paschale carmen Seduliusz wzoruje się na Metamorfozach. Podobnie jak Owidiusz, łączy całkiem odmienne, treściowo samodzielne opowieści ${ }^{20}$. Poszczególne relacje o starotestamentalnych cudach również stanowią osobne, zamknięte całostki ${ }^{21}$. Najdłuższa została poświęcona cudownym kolejom losu proroka Eliasza ${ }^{22}$, w najkrótszej poeta opowiada o przemawiającej ludzkim głosem oślicy Balaama ${ }^{23}$. Większość cechuje wręcz epigramatyczna zwięzłość kompozycji ${ }^{24}$.

Jak się wydaje, w odczuciu poety cudowny jest cały kosmos, stworzony i podtrzymywany w istnieniu przez Boga. Seduliusz zdaje sobie sprawę, że nie jest $\mathrm{w}$ stanie opowiedzieć o wszystkich znakach potęgi (virtutum signa ${ }^{25}$ ) Wszechmocnego ${ }^{26}$, których liczba przewyższa ilość gwiazd na niebie i ziare-

${ }^{15}$ Tamże I 295-296, Wójtowicz, s. 110.

${ }^{16}$ Tamże I 292-293, Wójtowicz, s. 110.

${ }^{17}$ Zgodnie z pierwotnym zamysłem autora poemat miał składać się z czterech ksiąg (por. Sedulius, Epistola ad Macedonium, Wójtowicz, s. 82-83). Niektóre rękopisy przekazują poemat podzielony na trzy księgi. Właśnie taką wersję utworu zna Izydor z Sewilli (Liber de viris illustribus 7 , ed. C. Codoñer Merino, Salamanca 1964, 138); por. T. Krynicka, „Desine gentilibus iam inservire poetis..." (Versus XI 9). Chrześcijańscy epicy w bibliotece Izydora z Sewilli, VoxP 34 (2014) t. 60, 201. Tymczasem w wydaniach ogłoszonych drukiem na poemat składają się przedmowa oraz pięć części; por. Wójtowicz, Wstęp, s. 11.

${ }^{18}$ Por. Sedulius, Paschale carmen I 107-120, Wójtowicz, s. 94-96.

${ }^{19}$ Por. tamże I 170-187, Wójtowicz, s. 100.

${ }^{20}$ Por. M. Mazzega, Sedulii Carmen paschale, Buch III, Basel 1996, 37-39, podaję za: Wójtowicz, Wstęp, s. 24.

${ }^{21}$ Por. Green, Latin Epics of the New Testament, s. 168.

${ }^{22}$ Por. Sedulius, Paschale carmen I 170-187, Wójtowicz, s. 100.

${ }^{23}$ Por. tamże I 160-162, Wójtowicz, s. 98.

${ }^{24}$ Por. Green, Latin Epics of the New Testament, s. 167.

${ }^{25}$ Sedulius, Paschale carmen I 95, Wójtowicz, s. 92.

${ }^{26}$ Por. tamże I 60, Wójtowicz, s. 90: „Omnipotens, aeterne Deus, spes unica mundi”. Zob. Ausonius, Ephemeris 3, 1, ed. R. Green, Oxford 1991, 8: „Omnipotens, solo mentis mihi cognite cultu". Inwokacja Seduliusza niewątpliwie zdradza wpływ lektury słynnej Modlitwy poety z Burdigali. Tegoż zdania jest R. Green (Latin Epics of the New Testament, s. 165-166). H. Wójtowicz (Inwokacja w ,Paschale carmen”, s. 38) odnotowuje ponadto zależność inwokacji od wielkich klasycznych epików (Wergiliusza, Owidiusza, Lukana, Syliusza Italika), a także Persjusza i Prudencjusza. 
nek piasku ${ }^{27}$. Relacjonując wybrane cudowne wydarzenia z czasów poprzedzających przyjście Chrystusa, najczęściej sięga po Księgę Wyjścia (5 razy) i Księgę Rodzaju (4 razy); w trzech przypadkach odwołuje się do Ksiąg Królewskich oraz do Księgi Daniela; zdradza znajomość Księgi Liczb, Jozuego i proroka Jonasza (po 1 relacji w oparciu o każdą). Dzięki temu przemierza w swej wyobraźni biblijne dzieje ludzkości od Henocha do Daniela, a więc od epoki patriarchów poprzez wyjście z Egiptu i wędrówkę Izraelitów do ziemi Kanaan, aż do okresu królewskiego i czasów niewoli babilońskiej.

1. Cud jako manifestacja Boga Zbawcy. Opowiadając o Bogu czyniącym cuda, Seduliusz postrzega Go przede wszystkim jako tego, który niesie człowiekowi ocalenie, uwalnia od zła i obdarza dobrem, czyli jest - zgodnie z przesłaniem Pisma Świętego - przede wszystkim Zbawicielem człowie$\mathrm{ka}^{28}$. W przypadku dziesięciu z osiemnastu nadzwyczajnych ingerencji Boga w ziemską rzeczywistość, które opisuje poeta, Bóg okazuje ludziom swą łaskawość z własnej inicjatywy, uprzedzając ich zasługi, a nawet prośby. Nawet wówczas, gdy autorzy biblijni informują, że człowiek doznawał cudownej pomocy Pana z powodu swej postawy wobec Niego, poeta skupia uwage tylko na działaniu Boga, całkowicie pomijając postępowanie tego, który go doświadczył. Nie wspomina, że Abraham i Sara zostali rodzicami mimo swego podeszłego wieku dzięki wierze patriarchy ${ }^{29}$, że Izraelici otrzymali mannę i gasili pragnienie wodą źródła, które wytrysnęło ze skały, gdyż Bóg usłyszał ich szemranie oraz wysłuchał próśb Mojżesza ${ }^{30}$, oraz że sprawiedliwy król Ezechiasz, zanim został uzdrowiony, z płaczem błagał Boga o zdrowie ${ }^{31}$. Poecie, który opanował sztukę zwięzłego opowiadania ${ }^{32}$, wystarczyłoby przecież kilka słów, by o tym napomknąć. Czy postępuje w ten sposób tylko dlatego, że jego czytelnik najprawdopodobniej wiedział o przemilczanych faktach? Czy też postrzega Boga jako tego, który pierwszy wychodzi człowiekowi naprzeciw w swojej łaskawości? Tak czy inaczej, nie ulega wątpliwości, że poemat nie jest jedynie sparafrazowaną wersją biblijnego passusu ${ }^{33}$,

\footnotetext{
${ }^{27}$ Por. Sedulius, Paschale carmen I 60-69 i 94-102, Wójtowicz, s. 92-94.

${ }^{28}$ Por. T. Jelonek, Teologia biblijna, Kraków 2011, 27-30.

${ }^{29}$ Por. Sedulius, Paschale carmen I 107-113, Wójtowicz, s. 94; Rdz 15, 6. O ile nie zostanie podane inaczej, Pismo Święte cytuję za: Pismo Święte Starego i Nowego Testamentu, oprac. zespół biblistów polskich z inicjatywy benedyktynów tynieckich, Poznań 2008.

${ }^{30}$ Por. Sedulius, Paschale carmen I 148-157, Wójtowicz, s. 98; Wj 16, 2-3; 17, 4.

${ }^{31}$ Por. tamże I 188-191, Wójtowicz, s. 100; 2Krl 20, 2-3.

${ }^{32}$ Por. Wójtowicz, Wstęp, s. 45-46.

${ }^{33}$ Por. E.R. Curtius, Literatura europejska i tacińskie średniowiecze, tłum. A. Borowski, Kraków 1997, 156: „Pozostało dotąd prawie niezauważone, że większa część wczesnochrześcijańskiej poezji stanowi kontynuację starożytnej retoryki parafrazowania”. Do autorów „przetwarzających Biblię w heksametry" wybitny badacz zalicza również „górnolotnego i zarozumiałego" (tamże, s. 157) Seduliusza, który parafrazuje ponadto swój poemat prozą, tworząc Paschale opus. Również M. Roberts (Biblical Epic and Rhetorical Paraphrase in Late Antiquity, Liverpool 1985, 5-36, po-
} 
lecz stanowi owoc lektury Pisma Świętego, której się podjął literat wrażliwy i twórczy, choć - rzecz jasna - wykształcony w rzymskiej szkole ${ }^{34}$, gdzie zgodnie z zaleceniami m.in. Kwintyliana uczył się alternatywnego odtwarzania tekstów wzorców ${ }^{35}$. Seduliusz tworzy własną opowieść o tych epizodach literackiego arcydzieła, jakim jest Pismo Święte, które szczególnie poruszyły jego wyobraźnię.

Seduliusz opisuje czytelnikowi jedynie dwie ingerencje Boga, które miały na celu wymierzenie kary. Zresztą kara jest nieodwracalna tylko w jednym przypadku: żona Lota zostaje zamieniona w słup soli, gdyż nie potrafi oderwać wzroku od ojczystego miasta, o którym biblijny autor mówi, iż zostało skazane na zagładę na mocy Bożego wyroku ${ }^{36}$. Nieznający litości, szalony w swoim gniewie Nabuchodonozor traci godność królewską i staje się współmieszkańcem dzikich zwierząt na długie siedem lat (septenaque tempora ${ }^{37}$ ), ale nie na zawsze. Zauważmy, iż kompetentny odbiorca poematu wiedział, iż natchniony autor wyraźnie mówi o wychowawczym wymiarze tego zdarzenia: udręki władcy trwają dokładnie tyle czasu, ile potrzebuje, aby nawrócić się do Boga i uznać Jego wszechmoc, a więc nauczyć się posłuszeństwa Jego nakazom i oddać Mu cześćc ${ }^{8}$. Ponadto poeta zauważa, iż nawet wymierzając Nabuchodonozorowi karę, Bóg nie przestaje troszczyć się o niego. Gdy wszyscy zapominają o dumnym królu, to właśnie On zapewnia mu pożywienie ${ }^{39}$.

Nie ulega wątpliwości, iż spadające na biblijnych bohaterów ciosy Seduliusz postrzega jako skutek działania rozgniewanego, wymierzającego karę, mszczącego krzywdy wyrządzone świętym Boga ${ }^{40}$. Jednak w odczuciu poety Bóg nawet wówczas, gdy karze, nie jest okrutny ani mściwy. Nieszczęścia ukaranych wynikają $z$ ich postawy i w pewnym sensie stanowią wyraz uszanowania Boga wobec ludzkich wyborów. Oglądająca się wstecz żona Lota na zawsze pozostała $\mathrm{w}$ miejscu, z którego było widać ruiny kwitnącej niegdyś Sodomy, z powodu własnych grzechów pogrążonej w piekielnym ogniu i zamienionej w chaos. Zdaniem Seduliusza na swój los zasłużył także król Babilonu. W swej głupocie (vecors) zapomniał on, iż jest tylko człowiekiem

daję za: G. Malsbary, Epic Exegesis and the Use of Vergil in the Early Biblical Poets, „Florilegium” 7:1985, 58-60) jest zdania, iż łacińska biblijna epika powstała wskutek sparafrazowania treści biblijnych przez jej autorów.

${ }^{34}$ Podobnie uważa G. Malsbary (Epic Epic Exegesis and the Use of Vergil, s. 60-61).

${ }^{35}$ Por. Quintilianus, Institutio oratoria X 5, 4-4, ed. L. Radermacher, Leipzig 1971, 278. Więcej o parafrazie, poziomach jej realizacji oraz potencjalnych modyfikacjach oryginalnych tekstów por. H. Lausberg, Retoryka literacka. Podstawy wiedzy o literaturze, thum. A. Gorzkowski, Bydgoszcz 2002, 561-562.

${ }^{36}$ Por. Sedulius, Paschale carmen I 121-122, Wójtowicz, s. 96; Rdz 18, 16-19. 29.

${ }^{37}$ Por. tamże I 210, Wójtowicz, s. 102.

${ }^{38}$ Por. tamże I 200-201 i 206-211, Wójtowicz, s. 102; Dn 4, 22-34.

${ }^{39}$ Por. tamże 235-236, Wójtowicz, s. 106.

${ }^{40}$ Por. tamże I 123, Wójtowicz, s. 96: ,ad poenam conversa suam [scil. uxor Loth]”; tamże I 206, Wójtowicz, s. 102: „mox perculit ultio regem”. 
oraz całkowicie wyrzekł się właściwej ludziom łagodności, łaskawości, dobroci (humana pietate recessit ${ }^{41}$ ). Przepędzony z królewskiego pałacu, kosmaty i zdziczały, włóczył się po górach i lasach; zamienił przepych wspaniałych uczt na trawę i wodę ze strumieni, którą pił leżąc na brzuchu ${ }^{42}$. Poeta twierdzi, iż była to digna ultio ${ }^{43}$ - zasłużona, godna takiego postępowania kara. Niewiarygodną degradację, która stała się udziałem dumnego władcy, uwypukla poprzez zastosowanie aliteracji, licznych hyperbatonów (1) i homoioteleutonów (2). Zaznacza też, iż opuszczonego przez wszystkich, potężnego niegdyś króla nie opuścił jedynie Bóg. Nawet karząc, nie przestaje On troszczyć się o Nabuchodonozora i zapewnia mu pożywienie, podobnie jak zapewnia je każdemu ze swoich stworzeń: per pascua regem / pavit ut hirsutam pecudem ${ }^{44}$.

Bóg jest w odczuciu autora Paschale carmen Bogiem bogatym w miłosierdzie. Chcąc opowiedzieć czytelnikowi niezwykłą historię Jonasza, poeta ani słowem nie wspomina o nieposłuszeństwie proroka wobec Jahwe, które spowodowało, iż znalazł się on w morskich odmętach, ale ukazuje brzuch wieloryba jako cudowny środek ocalenia krnąbrnego, lecz drogiego Panu sługi, który został skazany na zagładę ${ }^{45}$. Zauważmy, iż postępując w ten sposób Seduliusz nie tylko przekazuje swoim wykształconym czytelnikom, wierzącym i wciąż jeszcze dalekim od Kościoła ${ }^{46}$, wiedzę o historii zbawienia, lecz wzbudza w nich zaufanie i miłość wobec jej Sprawcy ${ }^{47}$.

2. Cud jako odpowiedź. Autorzy starotestamentalni opisują bardzo wiele przypadków, w których Bóg objawiał człowiekowi swój gniew, groził i wymierzał sprawiedliwość, domagał się ukarania tych, którzy Go znieważyli. Ralf Miggelbrink stwierdza, iż „Bóg Biblii nie tylko marginalnie, lecz z reguły

${ }^{41}$ Por. tamże I 207, Wójtowicz, s. 102.

${ }^{42}$ Por. tamże I 208-211, Wójtowicz, s. 102: „Agrestes (1a, 2a) pecudum consors fuit ille per herbas (1a, 2a) / Aulica (1b, 2b) depasto (1c, 2c) mutans convivia (1b, 2b) faeno (1c, 2c). / Pronus $\underline{a} \mathrm{~b}$ amne bibit (2d), septenaque tempora lustrat (2d)/ Omnibus hirsutus silvis et montibus errans

${ }^{43}$ Por. tamże I 206, Wójtowicz, s. 102.

${ }^{44}$ Por. tamże I 235-236, Wójtowicz, s. 106.

${ }^{45}$ Por. tamże I 192-196, Wójtowicz, s. 102; Jon 1.

${ }^{46}$ Gładysz (Dogmatyczne teksty w poetyckich utworach Seduliusza, s. 8 i 115-116, podaję za: H. Wójtowicz, Katecheza w poezji Seduliusza, w: Orbis antiquus: studia filologiczne i patrystyczne. Księga Pamiątkowa dedykowana Księdzu profesorowi Henrykowi Wójtowiczowi z okazji 70. rocznicy urodzin, red. N. Widok, Opole 1998, 29) pisze o tym, iż w poematach Seduliusza zawarta jest katecheza, przeznaczona dla szerszego ogółu wykształconych chrześcijan. Zdaniem M. Mazzegi (Sedulii Carmen paschale, s. 15, podaję za: Wójtowicz, Katecheza w poezji Seduliusza, 29) adresatami Paschale carmen są poganie, których Seduliusz chce prowadzić do nawrócenia. H. Wójtowicz (Katecheza w poezji Seduliusza, s. 39) przyjmuje, iż Seduliusz pisał przede wszystkim z myślą o poganach, lecz przy tym wcale nie wykluczał, iż jego poemat będą czytali również wykształceni chrześcijanie.

${ }^{47}$ Zdaniem J. Fontaine'a (Naissance de la poésie dans l'Occident chrétien, Paris 1981, 251), jest to naczelny cel poety: „Les procédés poétiques y sont mis au service du sentiment religieux, plus que de l'exégèse théologique". 
objawia się przez swój gniew" ${ }^{48}$. Jednak Seduliusz, jak zostało powiedziane wyżej, pisze jedynie o dwóch podobnych sytuacjach. Dlaczego spośród wielu ukaranych jego uwage przyciągnęli właśnie żona Lota oraz Nabuchodonozor? Przemiana pierwszej w słup soli jest bardzo dramatyczna i daje możliwość sporządzenia plastycznego opisu relacjonującemu ją literatowi. Możemy jedynie wyobrazić sobie, jak wspaniały opis podobnej metamorfozy mógłby wyjść spod rylca Owidiusza, który w sposób niezwykle finezyjny, plastyczny, „promieniująco poetycki” (według określenia Jerzego Danielewicza) opisał skamieniałą z bólu Niobe ${ }^{49}$. Nasz poeta poprzestaje jednak na stwierdzeniu: in statuam mutata salis stupefacta remansit $t^{50}$. Nabuchodonozor pojawia się w poemacie, być może, również dlatego, iż jest sprawcą okrutnej kaźni zgotowanej trzem młodzieńcom, cudownie wybawionym przez Boga, o czym poeta informuje $\mathrm{w}$ poprzedzającym fragmencie poematu ${ }^{51}$. Wydaje mi się, iż możemy przypuścić, że jednym, jeśli nie najważniejszym powodem, dla którego Seduliusz pisze o żonie Lota i Nabuchodonozorze, jest jego skrajnie negatywna ocena ich postępowania. Czyż dokonując takiego a nie innego wyboru poeta nie daje czytelnikowi do zrozumienia, iż w jego odczuciu największe zagniewanie Stwórcy powodują oczy odwrócone od oglądania wielkich dzieł Boga, zapatrzone w ohydną rzeczywistość grzechu, która wzbudza wstręt Wszechmogącego, a także serca nieznające litości, pyszne, okrutne wobec ludzi?

Bóg dokonuje cudów w odpowiedzi na postawę człowieka: karze grzeszników, śpieszy na ratunek wiernym, ocala ich od śmierci, żywi, spełnia ich pragnienia. Henoch nie doznał śmierci dzięki swoim dobrym czynom, które poeta określa przymiotnikiem vivax, sugerując, iż są one trwałe, nieprzemijające, zasługują na wieczną pamięć, jak też dają życie, są życiodajne ${ }^{52}$. Święta mądrość sprawiedliwego Abrahama każe mu wyzbyć się miłości wobec syna, by okazać większą, niż miłość do dziecka, miłość do Boga; nie zważać na rany Izaaka, lecz przylgnąć do Bożych nakazów. W swej szalonej, po ludzku rzecz biorąc, wierności Bogu doświadczy cudownego ocalenia dziecka, którego przyjście na świat też było skutkiem cudu ${ }^{53}$. Lśniący wspaniałymi zasługami (meritoque [...] fulgens ${ }^{54}$ ) Eliasz jest żywiony przez kruki, a u kresu dni zostaje uniesiony do nieba na ognistym rydwanie ${ }^{55}$. Płomienna wiara dziel-

${ }^{48}$ R. Miggelbrink, Gniew Boży. Znaczenie pewnej gorszącej tradycji biblijnej, tłum. A. Wałęcki, Kraków 2005, 5.

${ }^{49}$ Por. Ovidius, Metamorphoses 301-312, ed. R. Merkel, Lipsiae 1888, 115; zob. J. Danielewicz, Technika opisów w „,Metamorfozach” Owidiusza, Poznań 1971, 109-114.

${ }^{50}$ Sedulius, Paschale carmen I 122, Wójtowicz, s. 96.

${ }^{51}$ Por. tamże I 197-205, Wójtowicz, s. 102.

${ }^{52}$ Por. tamże I 103, Wójtowicz, s. 94: „,meritis vivacibus Enoch”. Zob. Plezia V 641-642, s.v. vivax.

${ }^{53}$ Por. tamże I 116-120, Wójtowicz, s. 94-96; Rdz 22, 1-18. Pisząc o Seduliuszowej wersji biblijnej opowieści o narodzinach i ocaleniu Izaaka, R. Green (Latin Epics of the New Testament, s. 167) uważa wręcz, iż poeta przedstawia w niej ,,a double miracle”.

${ }^{54}$ Sedulius, Paschale carmen I 185, Wójtowicz, s. 100.

${ }^{55}$ Por. tamże I 170-171, 179-183, Wójtowicz, s. 100; 1Krl 17, 1-7; 2Krl 2, 1-18. 
nych młodzieńców gasi płomień pieca, w który zostali wrzuceni, i okrywa ich wielką sławą ${ }^{56}$. Przed srogością głodnych lwów ratuje Daniela jego sprawiedliwośćc ${ }^{57}$. W dwóch relacjach Seduliusz daje do zrozumienia, iż również świętość człowieka, któremu Bóg przychodzi z pomocą, jest możliwa dzięki Bożemu wsparciu. Bohaterscy młodzieńcy, którzy wolą zginąć w płomieniach niż składać bałwochwalcze ofiary, działają natchnieni przez Boga, spirante $D e o^{58}$. Eliasz może nie tylko doświadczyć Bożych cudów, lecz sam - jako jedyny spośród starotestamentalnych bohaterów, o których pisze Seduliusz czyni liczne $\mathrm{cuda}^{59}$, dlatego że jest pełny Boga (plenus [...] Deo $)^{60}$.

3. Starotestamentalny cud jako zapowiedź rzeczywistości Nowego Testamentu. W żadnej z osiemnastu relacji o cudownych wydarzeniach, które miały miejsce przed narodzeniem Chrystusa, Seduliusz nie opisuje reakcji ludzi na cuda, których Bóg dla nich dokonał. Jak się wydaje, wolno przypuszczać, iż wobec wspaniałych dzieł Bożych odczuwali oni jeszcze większy zachwyt i głębszy podziw niż te, którym mistrzowsko daje wyraz poeta ${ }^{61}$. Pewni możemy być natomiast, iż chrześcijanin Seduliusz był zdolny odczytać wymowę wielkich starotestamentalnych znaków, nie zawsze dostępną tym, którzy ich bezpośrednio doświadczyli. Pisma Starego Testamentu przemawiają do poety, który dokonuje ich relektury w świetle Ewangelii, w sposób pełniejszy i głębszy niż do swoich ziemskich autorów i bezpośrednich odbiorców ${ }^{62}$, nieustannie też dąży on do wyjaśnienia ich ukrytej teologicznej wymowy swoim czytelni$\mathrm{kom}^{63}$. Dlatego w wydarzeniach starotestamentalnych Seduliusz niejednokrotnie - a dokładnie w 5 spośród 18 opowieści - dostrzega zapowiedź wydarzeń nowotestamentalnych ${ }^{64}$. Zabijając baranka, którego Bóg wybrał sobie na ofiarę zamiast Izaaka, Abraham ukazuje przyszłą ofiarę Chrystusa, który niczym święty baranek (homoioteleutyczne pius agnus ${ }^{65}$ ) swoją krwią zmyje grzechy ludzkości ${ }^{66}$. Co więcej, zdaniem poety, właśnie potrzeba prorockiego prze-

\footnotetext{
${ }^{56}$ Por. tamże I 197-205, Wójtowicz, s. 102; Dn 3, 8-97.

${ }^{57}$ Por. tamże I 215-216, Wójtowicz, s. 104: „,sed belua iusto / mitis facta viro”; Dn 6, 17-25.

${ }^{58}$ Por. tamże I 197, Wójtowicz, s. 102.

${ }^{59}$ Por. tamże I 176-177, Wójtowicz, s. 100.

${ }^{60}$ Por. tamże I 176, Wójtowicz, s. 100.

${ }^{61}$ Jak trafnie zauważa H. Wójtowicz (Wstęp, s. 29), Seduliusz chętnie posługuje się środkami poezji patetycznej, aby wzbudzać w czytelnikach poematu m.in. zdziwienie, zdumienie, wręcz osłupienie w obliczu opisywanych przezeń cudownych wydarzeń.

${ }^{62}$ Por. Jelonek, Teologia biblijna, s. 97-98.

${ }^{63}$ Zwraca na to uwagę R. Green (Latin Epics of the New Testament, s. 227), który pisze wręcz o „pervasive theological thrust” Seduliusza.

${ }^{64}$ Jak widzimy, wbrew temu, co twierdzi H. Wójtowicz (Inwokacja w „Paschale carmen”, s. 33), Seduliusz nie ogranicza się do relacjonowania czytelnikowi jedynie tych starotestamentalnych cudów, które mają charakter typiczny i mogą być interpretowane chrystologicznie.

${ }^{65}$ Sedulius, Paschale carmen I 120, Wójtowicz, s. 96.

${ }^{66}$ Typiczność ofiary Abrahama zauważają liczni Ojcowie Kościoła oraz twórcy najstarszej
} 
powiedzenia zgonu Zbawiciela spowodowała śmierć posłusznego zwierzęcia, które na rozkaz Boży dobrowolnie (sponte ${ }^{67}$ ) przychodzi do świętego ołtarza (podobnie brzmiące sacram [...] ad aram $^{68}$ ), by umrzeć. Seduliusz stwierdza wprost, iż krew baranka z góry Moria jest typem krwi Chrystusa (typicus cru$\left.o r^{69}\right)^{70}$. Poeta jest przekonany, iż o przyjściu Jezusa wiedziały spełniające wolę $\left(\right.$ famulata $^{71}$ ) Stwórcy ciała niebieskie ${ }^{72}$, które zatrzymując swój bieg pomogły odnieść zwycięstwo imiennikowi Zbawiciela, Jozuemu ${ }^{73}$.

Na prawdziwą ucztę duchową Seduliusz zaprasza czytelnika, gdy opowiada o znakach, towarzyszących wyjściu Izraela z Egiptu. Mówiąc o przejściu przez Morze Czerwone ${ }^{74}$, mannie ${ }^{75}$ i o wodzie, która wytrysnęła ze skały, nie tylko streszcza odpowiednie fragmenty Księgi Wyjścia, lecz mistrzowsko komentuje je odwołując się do innych miejsc w Starym i Nowym Testamencie ${ }^{76}$. Uważa, iż Syn Boży brał bezpośredni udział w opisywanych wydarzeniach i, rekapitulując je w odwrotnej kolejności ${ }^{77}$, stwierdza: Christus erat panis, Christus petra, Christus in undis ${ }^{78}$. Zrozumienie wypowiedzi poety umożliwia znajomość przytoczonych w Ewangelii według św. Jana słów Zbawiciela, który Żydom - domagającym się, by uczynił cud podobny do tego, jakiego doświadczyli ich ojcowie otrzymując na pustyni mannę - mówi, że to właśnie On jest prawdziwym chlebem z nieba, zaspokajającym głód człowieka i dającym życie światu (por. J 6, 31-35). Duchową skałą, która towarzyszyła Izraelitom w czasie wędrówki przez pustynię i dostarczała im napoju, nazwał Chrystusa

sztuki chrześcijańskiej, por. D. Forstner, Świat symboliki chrześcijańskiej, tłum. W. Zakrzewska - P. Pachciarek - R. Turzyński, wybór ilustracji i komentarz T. Łozińska, Warszawa 1990, 314.

${ }^{67}$ Sedulius, Paschale carmen I 224, Wójtowicz, s. 104.

${ }^{68}$ Tamże I 223, Wójtowicz, s. 104.

${ }^{69}$ Tamże I 120, Wójtowicz, s. 96.

${ }^{70}$ Zasługuje na uwagę interpretacja tego fragmentu poematu proponowana przez H. Wójtowicza (Alegoreza w „Paschale carmen” Seduliusza, s. 97-98), zgodnie z którą „Abraham oznacza Boga Ojca, Izaak - Syna Bożego, a baranek - pokorę. W Chrystusie są dwie natury [...], a jedna Osoba. Podobnie jak baranek został zabity na ofiarę, a Izaak pozostał przy życiu, tak ludzka natura Chrystusa podlegała cierpieniom, a Boska nie była im podległa”.

${ }^{71}$ Sedulius, Paschale carmen I 168, Wójtowicz, s. 100.

${ }^{72}$ Por. tamże I 168-169, Wójtowicz, s. 100: „iam tunc famulata videbant / Sidera venturum praemisso nomine Iesum".

${ }^{73}$ Por. Joz 10, 12-13. Według Księgi Liczb przywódca Izraela miał na imię Ozeasz (Lb 13, 16). Mojżesz zmienił jego imię na Jozue (hebr. Jehošua), sugerując, iż za pośrednictwem Jozuego Bóg będzie zbawiał swój lud, gdyż imię to oznacza „Jahwe jest zbawieniem”; zob. T. Jelonek, Księgi historyczne Starego Testamentu, Kraków 2006, 31-34.

${ }^{74}$ Por. Sedulius, Paschale carmen I 136-147, Wójtowicz, s. 96-98; Wj 14, 5-31.

${ }^{75}$ Wbrew temu, co twierdzi R. Green (Latin Epics of the New Testament, s. 167), Seduliusz nie opisuje cudu zesłania Izraelitom przepiórek (Wj 16, 9-13).

${ }^{76} \mathrm{C}$. Springer (The Gospel as Epic in Late Antiquity: The Paschale carmen of Sedulius, Leiden 1988, 13-14) pisze o „sophisticated exegesis” Seduliusza.

${ }^{77}$ Por. Wójtowicz, Alegoreza w ,Paschale carmen” Seduliusza, s. 98.

${ }^{78}$ Sedulius, Paschale carmen I 159, Wójtowicz, s. 98. 
Paweł Apostoł (por. 1Kor 10, 4; oraz J 4, 10-14). Słowa o Chrystusie, który był obecny pośród fal Morza Czerwonego, a nawet przewodził przemierzającym je Izraelitom, wyjaśnia sam poeta. Przytacza zatem wypowiedź psalmisty (Ps 28, 3): multas / vox Domini extat super aquas ${ }^{79}$, a następnie, po raz kolejny dowodząc swego zamiłowania do synonimii ${ }^{80}$, thumaczy, iż wyraz vox (wyeksponowany poprzez epanaforę) jest synonimem rzeczownika verbum (wyeksponowanego poprzez to, że dzięki elizji zamyka on wers 144, a następnie otwiera wers 145$)^{81}$, po czym, nawiązując do prologu Ewangelii Janowej, stwierdza: Verbum Christus adest ${ }^{82}$. W odczuciu autora poematu Syn Boży jest panem wydarzeń opisanych zarówno w Starym, jak też w Nowym Testamencie, pomiędzy którymi panuje doskonała zgoda: geminae qui consona legis / Testamenta regent $^{83}$. Działając w czasach starotestamentalnych, przygotowuje On swoje przyjście. To właśnie Chrystus - Seduliusz z mocą podkreśla to poprzez użycie czasownika patefacio na początku i na końcu relacji - otwiera przed Izraelem odwieczną morską otchłań ${ }^{84}$, torując drogę nauce, którą Bóg powierza swemu narodowi, by następnie ogłosić ją całemu światu: ut doctrina sequens planis incederet arvis ${ }^{85}$. W wodach Morza Czerwonego udziela On rude baptisma ${ }^{86}$ - niedoskonałego, niedojrzałego, zalążkowego - chciałoby się powiedzieć chrztu, niejako kładąc początki pierwszego sakramentu Kościoła ${ }^{87}$.

A zatem zbawcze dzieło Jezusa rozpoczyna się na długo przed Jego przyjściem na świat. Co więcej, wypowiedziane przez Niego słowa pomagają,

${ }^{79}$ R. Green (Latin Epics of the New Testament, s. 228-229) zwraca uwagę, iż wyjaśniając Pismo Święte poprzez odwołanie do innych fragmentów Biblii, Seduliusz bardzo często powołuje się na psalmy. O swej miłości do nich mówi sam poeta w Paschale carmen I 23 (Wójtowicz, s. 88: „ego, Daviticis adsuetus cantibus").

${ }^{80} \mathrm{Na}$ urozmaicenie opisów cudów poprzez ,pełną artyzmu zmianę użycia słów” zwraca uwagę H. Wójtowicz (Wstęp, s. 27). Również w analizowanym fragmencie na uwagę zasługują liczne synonimiczne określenia, m.in. morza (Sedulius, Paschale carmen I 136-146. 159, Wójtowicz, s. 96-98: caerula, ponti, pelagi, mare, profundum, aequor, abyssum, undis), deszczu (tamże I 148151, Wójtowicz, s. 98: nimbis, pluviis, imbris), ognia (tamże I 127-131, Wójtowicz, s. 96: ignibus, flagrans, ardens, ardere, torrida, aestu, flammae; tamże I 200-205, Wójtowicz, s. 102: accenderat, fornace, ignes, rogo, ardore, calentes, incendia, flammis, ardentis, camini), thumu (tamże I 138, Wójtowicz, s. 98: turba; tamże I 142, Wójtowicz, s. 98: populus; tamże I 148, Wójtowicz, s. 98 : catervas; tamże I 152, Wójtowicz, s. 98: exercitus).

${ }^{81}$ Por. Sedulius, Paschale carmen I 144-145, Wójtowicz, s. 98: „Vox Domini super extat aquas, vox denique verbum est. / Verbum Christus adest".

${ }^{82}$ Tamże I 145, Wójtowicz, s. 98; J 1, 1-5.

${ }^{83}$ Tamże I 145-146, Wójtowicz, s. 98.

${ }^{84}$ Por. tamże I 136, Wójtowicz, s. 96: „patuerunt caerula ponti”; tamże I 146, Wójtowicz, s. 98: „patefecit abyssum”.

${ }^{85}$ Por. tamże I 147, Wójtowicz, s. 98.

${ }^{86}$ Por. tamże I 142, Wójtowicz, s. 98.

${ }^{87}$ Podobnie jak Apostoł Piotr $(1 \mathrm{P} 3,21)$ i liczni pisarze wczesnochrześcijańscy, poeta widzi figurę chrztu również w potopie. Por. Sedulius, Paschale carmen I 73-78, Wójtowicz, s. 92. Zob. Forstner, Świat symboliki chrześcijańskiej, s. 313. 
zdaniem Seduliusza, zrozumieć Boże przesłanie starotestamentalnych cudów. Zasługuje na uwagę, iż relacjonując wyjście Lota z Sodomy, poeta poświęca bratankowi Abrahama pół wersu ${ }^{88}$, jego żonie - dwa wersy ${ }^{89}$, a wyjaśnieniu przyczyn nieszczęścia, które spotkało tę najbardziej tragiczną postać omawianego fragmentu poematu - trzy i pół wersu ${ }^{90}$. Poeta tłumaczy, iż chcąc uniknąć zgubnych niebezpieczeństw tego świata, nie powinniśmy - podobnie jak oracz, o którym mówił Jezus swemu niedoszłemu naśladowcy - oglądać się wstecz (por. Łk 9, 62) $)^{91}$.

\section{Subditur omnis imperiis natura tuis ${ }^{92}$. Cud jako zjawisko nadnatu-} ralne. W podniosłej epickiej inwokacji poeta wyraża nadzieję, iż sprosta trudnemu zadaniu, jakiego się podejmuje, z pomocą Boga, który stwarzając świat ustanowił rządzące naturą prawa, toteż jako jedyny ma przywilej zawieszania ich działania. Na rozkaz Stwórcy wszelkie stworzenie całkowicie zmienia swoją postać; od Niego, a nie od pór roku, ostatecznie zależą procesy wegetacji; Jemu podporządkowany jest nieubłagany wobec ludzi czas ${ }^{93}$. Właśnie wówczas, gdy Bóg wkracza w ustanowiony przezeń prządek świata i zawiesza rządzące nim prawa, ma miejsce cud. W odczuciu Seduliusza cudownym jest zatem wydarzenie nadnaturalne, dziejące się wbrew prawom natury, mimo iż wykazując się wielką ludzką i religijną wrażliwością; zauważa on również cudowność całego stworzenia, które jest znakiem Bożej wszechmocy i dobro$\mathrm{ci}^{94}$. W nadzwyczajnych starotestamentalnych wydarzeniach, których przebieg relacjonuje, następuje: a) zatrzymanie, a nawet odwrócenie upływu czasu, b) zmiana właściwości żywiołów oraz c) usposobienia zwierząt. Ponadto d) przestaje działać kara, nałożona przez Boga na rodzaj ludzki po grzechu prarodziców: ludzie nie muszą pracować, aby w pocie czoła otrzymywać pokarm, nie ulegają też śmierci. W dalszej części artykułu proponuję przyjrzeć się tekstom, w których poeta ukazuje wyróżnione wyżej cudowne wydarzenia.

a) Zatrzymanie bądź odwrócenie upływu czasu. Cudowne zatrzymanie upływu czasu następuje w czasie bitwy Izraelitów pod wodzą Jozuego ze sprzymierzonymi królami amoryckimi. Jego widomym znakiem staje się zatrzymanie na niebie słońca i księżyca. Seduliusz nie opowiada o okolicznościach niezwykłego wydarzenia, lecz natychmiast wprowadza kompetentnego czytelnika in medias res, oznajmiając: Sol stetit ad Gabaon ${ }^{95}$. Następnie kieruje wzrok czytelnika w górę precyzując, iż słońce stanęło

\footnotetext{
${ }^{88}$ Por. Sedulius, Paschale carmen I 121, Wójtowicz, s. 96.

${ }^{89}$ Por. tamże I 121-123, Wójtowicz, s. 96.

${ }^{90}$ Por. tamże I 123-126, Wójtowicz, s. 96.

${ }^{91}$ Por. tamże: „quia nemo retrorsum, / Noxia contempti vitans discrimina mundi / Aspiciens salvandus erit, nec debet arator / Dignum opus exercens vultum in sua terga referre".

${ }^{92}$ Tamże I 85-86, Wójtowicz, s. 92.

${ }^{93}$ Por. tamże I 60-85, Wójtowicz, s. 90-92.

${ }^{94}$ Por. tamże I 61-69, Wójtowicz, s. 90-92. Zob. Jelonek, Teologia biblijna, s. 146-147.

${ }^{95}$ Sedulius, Paschale carmen I 163, Wójtowicz, s. 98.
} 
niejako w samym centrum świata, bo „na szczycie środka nieba (mediique cacumine caeli)" "96. Powstrzymując wieczór, który, jak się domyślamy, zmierzał w stronę nocy, słońce z całą mocą zatrzymało (fixit) zmęczone, wyczerpane długim dniem światło (anhelantem [...] lucem ${ }^{97}$ ). Posłuszne Stwórcy, zatrzymały się szybkie godziny (rapidas [...] distulit horas $^{98}$ ); zwolnił również księżyc, który nagle stał się ociężały (pigra) i zaprzestał przemierzania swojej zwykłej drogi ${ }^{99}$. Poeta jak gdyby sugeruje, iż same ciała niebieskie były zdumione tym, co się działo, gdy zauważa, iż słońce nie przywykło do powstrzymywania dnia - insolitus frenare diem ${ }^{100}$. Podczas gdy natchniony autor mówi, iż to Pan walczył za naród wybrany (por. Joz 10,14), Seduliusz czyni sprzymierzeńcem siejącego spustoszenie izraelskiego oręża właśnie niebo ${ }^{101}$.

Błogosławionych skutków odwrócenia czasu doświadczyli Abraham i Sara. Oboje byli w bardzo podeszłym wieku, gdy począł się ich pierworodny syn, w którym zabłysła im nadzieja otrzymania wielu wspaniałych potomków (spem gentis opimae ${ }^{102}$ ). Seduliusz podkreśla cudowność narodzin Izaaka, mistrzowsko ukazując starość bohaterów, całkowicie niezdolnych do wydania potomstwa. W tym celu gromadzi liczne wyrazy, które opisują starcze (vetulae, grandaevo, annoso, seniore) wyczerpanie (marcebant, consumpta) ich ciał - schorowanych (saucia), zimnych (frigidus, gelidi, algentes), niczym już umarłych (moriens), od zawsze stawiających opór przekazaniu życia (consumpta situ, prolemque negabat) ${ }^{103}$. Starość matki uwypukla ponadto za pomocą hyperbatonu połączonego z homoioteleutonem: vetulae [...] Sara ${ }^{104}$, serum [...] natum ${ }^{105}$; podeszły wiek Abrahama podkreśla, stosując rozbudowany, niejako przenikający cały wers hyperbaton, którego poszczególne człony są zakończone na literę „,": frigidus annoso moriens in corpore sanguis ${ }^{106}$. Obraz cudownych narodzin zamyka ukazując Sarę - którą wyróżnia poprzez to, iż jako jedyną postać w opowie-

${ }^{96}$ Tamże, Wójtowicz, s. 98-99.

${ }^{97}$ Tamże I 164, Wójtowicz, s. 98.

${ }^{98}$ Tamże I 230, Wójtowicz, s. 104.

${ }^{99}$ Por. tamże I 165-166, Wójtowicz, s. 100.

${ }^{100}$ Tamże I 165, Wójtowicz, s. 100.

${ }^{101}$ Por. tamże I 166-168, Wójtowicz, s. 100: „donec populantibus armis / Fervidus ingentem gladius consumeret hostem / coniurante polo".

102 Tamże I 112, Wójtowicz, s. 94.

${ }^{103}$ Por. tamże I 107-111, Wójtowicz, s. 94: „Saucia iam vetulae marcebant viscera Sarae / Grandaevo consumpta situ, prolemque negabat / Frigidus annoso moriens in corpore sanguis: / cum seniore viro gelidi praecordia ventris / In partum tumere novum tremebundaque mater / algentes onerata sinus".

${ }^{104}$ Tamże I 107, Wójtowicz, s. 94.

${ }^{105}$ Tamże I 113, Wójtowicz, s. 94. Seduliusz bardzo chętnie łączy hyperbatony z homoioteleutonami, por. tamże I 104. 120. 124. 132. 136. 148. 150. 152. 157-158. 162. 164. 167-168. 196. 199. 200. 203. 170. 172-173. 179-180. 183-184. 203. 206. 209. 212 i 215, Wójtowicz, s. 94-104.

${ }^{106}$ Tamże I 109, Wójtowicz, s. 94. 
ści o Izaaku nazywa po imieniu - z dzieckiem zawieszonym u piersi: serum suspendit ad ubera natum ${ }^{107}$.

Jahwe jest panem czasu. Gdy dni króla Ezechiasza nieubłaganie zmierzały do swego kresu - poeta uwypukla stopniowe, niezauważalne, nieodwracalne zanikanie jego życia stosując połączony z aliteracją hyperbaton labentis [...] lucis ${ }^{108}$ - zdjęty litością (miseratus ${ }^{109}$ ) Bóg, na mocy przysługującej mu władzy (iure $s u o^{110}$ ), dodał do ostatnich chwil króla (ultima tempora ${ }^{111}$ ) jeszcze 15 lat (peryfrastycznie opisane ter quinos [...] annos ${ }^{112}$ ), okazując się $\mathrm{w}$ ten sposób również władcą życia i śmierci. Zbawczą ingerencję Bożą w losy Ezechiasza poeta opisuje barwnie i obrazowo. Ukazuje mianowicie Boga, który szybko (wrażenie szybkości, z którą działa Bóg, autor poematu osiąga opisując jedną z wykonywanych przez Niego czynności za pomocą imiesłowu) wkracza pomiędzy wyczekującą na króla śmierć oraz jego życie. Zamykając stojące otworem przed Ezechiaszem bramy tej pierwszej, zawraca jego zmierzające ku zachodowi życie i nakazuje mu udać się w kierunku nowego początku: $a b$ occasu $[. .$.$] in ortum { }^{113}$.

b) Zmiana właściwości żywiołów. Człowiek nie może być pewny niczego, gdy w dzieje świata wkracza Bóg, Pan czasu i Władca żywiołów. On sprawia, że groźny ogień płonie, ale nie spala ognistego krzewu ${ }^{114}$. Zauważmy, iż o tym, że w nim ukazał się pasącemu owce Mojżeszowi Anioł Pański (por. Wj 3, 1-6), wie kompetentny czytelnik, ale milczy poeta, zafascynowany płomieniem pieszczotliwie muskającym liście, któremu poświęca zamykający relację złoty wers. Na uwagę zasługują składające się nań liczne instrumentacje głoskowe, homoioteleutony i przerzutnie. Czytając of frondea [...] robora dotykamy szorstkich, twardych, sztywnych liści pustynnej rośliny, która broni się przed utratą wody; dzięki kolejnej mistrzowsko zbudowanej synestezyjnej konstrukcji blanditiae lambebant [...] flammae czujemy zaskakująco orzeźwiający, jak połączenie wargowych -b, -m, -f z płynną -1 i szeroką -a, dotyk płomyków ${ }^{115}$. Zauważmy, iż zarówno poeta, jak też jego rzymscy czytelnicy prawdopodobnie kojarzyli ów cudowny biblijny ogień z płomieniem, który płonął wokół główki Julusa, nie wyrządzając dziecku krzywdy i wprawiając w zdumienie Eneasza i jego żonę ${ }^{116}$.

${ }^{107}$ Tamże I 113, Wójtowicz, s. 94.

${ }^{108}$ Tamże I 188, Wójtowicz, s. 100. Połączenie hyperbatonu z aliteracją znajdujemy również w Paschale carmen I 161 i 189, Wójtowicz, s. 98-100.

${ }^{109}$ Tamże I 188, Wójtowicz, s. 100.

${ }^{110}$ Tamże I 190, Wójtowicz, s. 100.

${ }^{111}$ Tamże I 188, Wójtowicz, s. 100.

112 Tamże I 189, Wójtowicz, s. 100. Por. tamże I 233, Wójtowicz, s. 104: „Adiecit tria lustra viro”.

113 Tamże I 191, Wójtowicz, s. 100. Por. tamże I 190-191, Wójtowicz, s. 100: „patefactaque limina claudens / Mortis ab occasu vitam convertit in ortum"; 2Krl 20, 1-7.

${ }^{114}$ Por. tamże I 127-131, Wójtowicz, s. 96.

${ }^{115}$ Por. tamże I 131, Wójtowicz, s. 96: „Frondea blanditiae lambebant robora flammae”.

116 Por. Vergilius, Aeneis II 680-686, spec. 683-684, ed. R. Pichon, Paris 1916, 313: „tactuque innoxia molles / Lambere flamma comas". 
Szczególną uwagę należy zwrócić na wyjątkowo bogaty w środki stylistyczne opis przejścia Izraelitów przez Morze Czerwone. Morze, na określenie którego Seduliusz używa aż ośmiu bliskoznacznych rzeczowników ${ }^{117}$, jest ukazane niezwykle obrazowo. Czytamy, iż zostaje rozdzielone (divisi [...] ponti ${ }^{118}$ ), zwinięte na dwie strony (in geminum revoluta latus ${ }^{119}$ ), pozbawione morskich fal (absentis pelagi mare ${ }^{120}$ ). Poeta personifikuje morskie dno: obnażone (nudataque tellus ${ }^{121}$ ) i złupione $\mathrm{z}$ towarzyszących mu od zawsze wód (cognatis spoliatur aquis ${ }^{122}$ ), wysuszone i zdumione podziwia ono kroki obcych przybyszów (Sicca peregrinas stupuerunt marmora plantas ${ }^{123}$ ). Lazurowe tonie stają otworem przed narodem wybranym (patuerunt caeru$l a^{124}$ ), który następnie wkroczy na wypaloną słońcem równinę, pozbawioną nadziei napicia się wody i życia ${ }^{125}$. Susza nie zgładzi Izraelitów, podobnie jak nie zgubiły ich morskie odmęty. Wprawdzie doświadczają oni udręki pragnienia - jedno ze słów-kluczy fragmentu to uwypuklony dzięki hyperbatonom, aliteracji, homoioteleutonom wyraz sitis ${ }^{126}$ - jednakże stają się świadkami nagłego wytryśnięcia wody (połączona $\mathrm{z}$ hyperbatonem hypallage subitas [...] aquas $^{127}$ ) z wyschłego głazu (arente metallo ${ }^{128}$ ), z bezpłodnej skały (sterilique $[\ldots]$ de rupe $\left.{ }^{129}\right)$, z jałowego kamienia (ieiuna $[. .$.$\left.] marmora ^{130}\right)(\mathrm{Wj} 17,1-7)$, z głębi wzgórza (saxo [...] ab imo ${ }^{131}$ ).

c) Zmiana usposobienia zwierząt. Moc Bożą wyczuwają i korzą się przed nią również pozbawione rozumu zwierzęta. Okazują one posłuszeństwo swemu Stwórcy i spełniają Jego wolę, nawet jeśli oznacza to, iż mają postąpić wbrew swoim instynktom i zwyczajom. Seduliusz odnotowuje udział zwierząt w sześciu z osiemnastu relacji, przy czym ich rola w opisywanych wydarzeniach jest kluczowa. Warto zauważyć, iż wśród prezentowanych zwierząt są łagodni roślinożercy, jak również wzbudzające postrach drapieżniki, zwierzęta morskie, ptaki i gady ${ }^{132}$.

\footnotetext{
117 Por. nota 80 .

${ }^{118}$ Sedulius, Paschale carmen I 136, Wójtowicz, s. 96.

${ }^{119}$ Tamże I 137, Wójtowicz, s. 96.

${ }^{120}$ Tamże I 139, Wójtowicz, s. 98.

${ }^{121}$ Tamże I 137, Wójtowicz, s. 96.

${ }^{122}$ Tamże I 138, Wójtowicz, s. 98.

${ }^{123}$ Tamże I 140, Wójtowicz, s. 98.

124 Tamże I 136, Wójtowicz, s. 96.

${ }^{125}$ Por. tamże I 153-154, Wójtowicz, s. 98: „diu qua terra negatis / Aegra iacebat aquis, qua spes ablata bibendi / Vivendique fuit".

${ }^{126}$ Por. tamże I 152-153, Wójtowicz, s. 98: „Rursus in exustis sitiens exercitus arvis / Qua nimium loca sicca, diu qua terra negatis".

${ }^{127}$ Tamże I 155-156, Wójtowicz, s. 98.

${ }^{128}$ Tamże I 155, Wójtowicz, s. 98.

${ }^{129}$ Tamże I 156, Wójtowicz, s. 98.

${ }^{130}$ Tamże I 157, Wójtowicz, s. 98.

${ }^{131}$ Tamże I 228, Wójtowicz, s. 104.

${ }^{132} \mathrm{~W}$ węża zostaje zamieniona laska Aarona (por. Sedulius, Paschale carmen I 132-135, Wój-
} 
Na rozkaz Boży do ołtarza, na którym ma zostać złożony w ofierze Izaak, z własnej woli przychodzi baranek ${ }^{133}$. Groźne, pozbawione pokarmu lwy (ieiunis [...] feris ${ }^{134}$ ), którym wrzucono na pożarcie Daniela, łagodnieją (belua [...] / mitis facta ${ }^{135}$ ), poskramiają szaloną wściekłość (rabies mollita furorem / deposuit ${ }^{136}$ ), przestają wydawać groźne ryki (saevisque in faucibus ira quie$v i t^{137}$ ) - jak się wydaje, poeta znał te zwierzęta z autopsji, skoro jego zdaniem właśnie gardło jest siedzibą lwiego gniewu - i chętnie rezygnują z możliwości zaspokojenia głodu (coepit amare famem ${ }^{138}$ ). Co więcej, poeta zaznacza, iż postępując $\mathrm{w}$ ten sposób, bezwzględne bestie, których ryk zastygł w nagromadzonych w wersie zgłoskach -r, uczą się zachowywania przy życiu swej zdobyczy: Et didicere truces praedam servare leones ${ }^{139}$. Tak więc posłuszne Stwórcy drapieżne zwierzęta wykazały się cechami, które zwykliśmy określać jako „ludzkość”, w większej mierze, niż grzeszny, szalony w swej pysze król Dariusz ${ }^{140}$. Podobnie siorbiący wodę wieloryb (coetu sorbente ${ }^{141}$ ), który połknął wyrzuconego ze statku Jonasza, okazał prorokowi więcej serca, niż współtowarzysze podróży. Potraktował go nie jak łup, ale jak umieszczony we własnych trzewiach cenny ładunek (depositum, non praeda fuit ${ }^{142}$ ) i - mimo swej wrogości wobec ludzi (inimico remige ${ }^{143}$ ) - nietkniętego dostarczył do celu $^{144}$.

Niewiarygodną przygodę przeżywa oślica Balaama, której Seduliusz poświęca zwięzłą, trzywierszową, lecz niezwykle kunsztowną relację ${ }^{145}$. Podczas gdy natchniony autor informuje, że przerażone widokiem anioła zwierzę zboczyło z drogi, zostało trzykrotnie zbite przez swego pana, po czym Bóg pozwolił mu przemówić w obronie własnej sprawy (por. Lb 22, 21-30), poeta przedstawia towarzyszące cudownemu wydarzeniu okoliczności w trzech słowach: angelicis tremefacta minis ${ }^{146}$. Ukazuje trzy osoby działające: anioła, człowieka i zwierzę. Wysłaniec Boga jest obecny jedynie dzięki wzmiance o jego groźbach, jeźdźca poeta czyni dopełnieniem bliższym przy czasowniku

\footnotetext{
towicz, s. 96. Ów wąż zachowuje się jednak zgodnie ze swą naturą, toteż wspomniane wydarzenie zostanie omówione w 5 punkcie artykułu (Cud jako metamorfoza).

${ }^{133}$ Sedulius, Paschale carmen I 114-115, Wójtowicz, s. 94.

${ }^{134}$ Tamże I 215, Wójtowicz, s. 104.

${ }^{135}$ Tamże I 215-216, Wójtowicz, s. 104.

${ }^{136}$ Tamże I 217-218, Wójtowicz, s. 104.

${ }^{137}$ Tamże I 218, Wójtowicz, s. 104.

${ }^{138}$ Tamże I 217, Wójtowicz, s. 104.

${ }^{139}$ Tamże I 219, Wójtowicz, s. 104.

${ }^{140}$ Por. tamże I 212, Wójtowicz, s. 102.

${ }^{141}$ Tamże I 192, Wójtowicz, s. 102.

${ }^{142}$ Tamże I 195, Wójtowicz, s. 102.

${ }_{143}$ Tamże I 196, Wójtowicz, s. 102.

${ }^{144}$ Por. tamże I 196, Wójtowicz, s. 102; Jon 2.

${ }^{145}$ Por. tamże I 160-162, Wójtowicz, s. 98.

${ }^{146}$ Tamże I 160, Wójtowicz, s. 98.
} 
opisującym cud. W centrum uwagi znajduje się oślica - podmiot i główna bohaterka opowieści. Przestraszone zwierzę przemawia do swego pana za pomocą słów (adfatur [...] / sessorem per verba suum ${ }^{147}$ ). Chcąc uzmysłowić czytelnikowi niewiarygodność tego faktu, Seduliusz wyjaśnia, iż to pogardzane, wykorzystywane do przewożenia najcięższych ładunków, pokorne i „głupie” w opinii ogółu ${ }^{148}$ bydlę (animal pecuale ${ }^{149}$ ) swym ryczącym, nienawykłym do ludzkiej mowy głosem (linguaque rudenti ${ }^{150}$ ), naprawdę wymówiło będące w użyciu u ludzi słowa (wyróżnione za pomocą homoioteleutonu i hyperbatonu humanas loquellas ${ }^{151}$ ). Zauważmy, iż poeta wyraźnie darzy oślicę sympatią, gdyż mówiąc o niej stosuje zdrobnienie asella ${ }^{152}$.

Głębokie przesłanie teologiczne znajdujemy w opowieści o krukach, które przynosiły obfity (sine more ${ }^{153}$ ) pokarm Eliaszowi. Usługując prorokowi, te drapieżne ptaki zapomniały o właściwej im chciwości i dostarczały mu nienadgryzione jedzenie ${ }^{154}$. Żeby zrozumieć myśl autora poematu, należy wziąć pod uwagę, iż wielu Ojców Kościoła postrzegało kruka jako symbol nieczystości, grzechu, zatwardziałości serca ${ }^{155}$. Również Seduliusz w Elegii na cześć Chrystusa utożsamia je z bezbożnymi heretykami ${ }^{156}$. W poemacie zauważa, iż ptak ten wykazał się wiarołomstwem wobec Noego, popełniając występek w czasie potopu ${ }^{157}$. Być może, pisząc w ten sposób poeta nawiązuje do wersji wydarzeń przedstawionej w Septuagincie. Jej autorzy przekazują, iż Noe nadaremnie usiłował wysłać kruka na zwiady: ptak nie chciał okazać mu posłuszeństwa i nie opuścił arki ${ }^{158}$. Według Wulgaty kruk wylatywał i powracał aż do czasu, gdy wody ustąpiły z powierzchni ziemi ${ }^{159}$. Istnieje związana

${ }^{147}$ Tamże I 160-161, Wójtowicz, s. 98.

${ }^{148}$ Por. Forstner, Świat symboliki chrześcijańskiej, s. 285; B. Szczepanowicz-A. Mrozek, Atlas zwierząt biblijnych: miejsce w Biblii i symbolika, Kraków 2007, 51-53.

${ }^{149}$ Tamże I 162, Wójtowicz, s. 98.

${ }^{150}$ Tamże I 161, Wójtowicz, s. 98.

${ }^{151}$ Tamże I 162, Wójtowicz, s. 98.

152 Tamże I 162, Wójtowicz, s. 98. Por. Plezia I 271, s.v. asella.

${ }^{153}$ Sedulius, Paschale carmen I 171, Wójtowicz, s. 100.

${ }^{154}$ Por. tamże I 171-173, Wójtowicz, s. 100: ,alesque rapinis / Deditus atque avido saturans cava guttura rostro / Tradidit inlaesam ieiunis morsibus escam".

${ }^{155}$ Por. Forstner, Świat symboliki chrześcijańskiej, s. 237-238.

${ }^{156}$ Por. Sedulius, Hymnus 1, 101-104, Wójtowicz, s. 232-234; zob. H. Wójtowicz, Elegia Seduliusza, w: Elegia poprzez wieki. Konferencja naukowa 8-9 XI 1994, red. I. Lewandowski, Poznań 1995, 113.

${ }^{157}$ Por. tenże, Paschale carmen I 174-175, Wójtowicz, s. 100: „Nunc bonus Heliae, qui perfidus antea Noe, / Abluit in terris quidquid deliquit in undis".

${ }^{158}$ Por. Rdz 8, 6-7, w: Septuaginta czyli Biblia Starego Testamentu wraz z księgami deuterokanonicznymi i apokryfami, przełożył, przypisami i wstępem opatrzył R. Popowski, Warszawa 2013, 15): „Czterdzieści dni później Noe otworzył okno, które zrobił w arce, i wypuścił kruka, aby sprawdzić, czy opadły wody. Choć mógł wylecieć, nie chciał się oddalić, dopóki nie wyschną wody na ziemi".

${ }^{159}$ Por. Rdz 8, 6-7, w: Biblia Sacra iuxta vulgatam versionem, ed. R. Weber, Stuttgart 1983, 13: 
z tym przekazem tradycja, zgodnie z którą kruk pozostał poza arką, żywiąc się padliną ${ }^{160}$. Pisze o tym Ambroży z Mediolanu ${ }^{161}$, autor dobrze znany Seduliuszowi ${ }^{162}$. A zatem twórca Paschale carmen po raz kolejny jawi się jako poeta rozmiłowany $\mathrm{w}$ snuciu teologicznych refleksji ${ }^{163}$. Tym razem przekonuje on czytelnika, iż Bóg może sprawić, że nieczysty ptak, którego Izraelitom nie wolno było spożywać, posila Jego świętych ${ }^{164}$; najbardziej zatwardziały grzesznik potrafi przyczynić się do ocalenia sprawiedliwego ${ }^{165}$; istota napiętnowana złem staje się narzędziem Opatrzności ${ }^{166}$.

d) Cud jako zapowiedź zbawczej reintegracji kosmosu. Grzech pierwszych ludzi zerwał ich więzy ze Stwórcą oraz zburzył harmonię, która dotąd panowała w stworzonym świecie, wprowadził doń cierpienie i śmierć. Ingerując w dzieje człowieka, Bóg Zbawca przypomina, iż jest dawcą obfitości życia. Cuda przypominają raj przed upadkiem człowieka; zapowiadają też redemptio cosmica, jaka ma nastąpić na końcu czasów. Dokonując cudów, Bóg niejako zawiesza, na pewien moment czasu i w pewnym miejscu w przestrzeni, karę nałożoną na Adama i Ewę. Człowiek doświadczający cudu nie musi zdobywać w pocie czoła swego pożywienia, co więcej - nie powraca do ziemi wskutek śmiertelnego rozkładu. Słuszność takiej interpretacji analizowanych fragmentów Paschale carmen potwierdza sam Seduliusz, który w swej Elegii wprost oświadcza, iż przeniesienie Henocha do nieba przypomina, jakie miejsce ludzkość utraciła z powodu grzechu i jakie otrzyma w przyszłości dzięki łasce Boga ${ }^{167}$.

Prawdziwy zachwyt autora poematu wzbudza otrzymana przez Izraelitów na pustyni manna. Jej krótki ${ }^{168}$, lecz niezwykle kunsztowny ${ }^{169}$ opis Seduliusz

„Cumque transissent quadraginta dies, aperiens Noe fenestram arcae, quam fecerat, dimisit corvum; qui egrediebatur exiens et rediens, donec siccarentur aquae super terram".

${ }^{160}$ Wbrew D. Forstner (Świat symboliki chrześcijańskiej, s. 237-238), nie ma o tym mowy w Septuagincie.

${ }^{161}$ Por. Ambrosius Mediolanensis, De Noe et arca 17, 62, PL 14, 411. O trwaniu tej tradycji świadczy fakt, iż znajduje ona wyraz w dwunastowiecznym Aviarium (II 10) Hugona z Folieto, por. Fizjologi i Aviarium. Średniowieczne traktaty o symbolice zwierząt, thum. i oprac. S. Kobielus, Tyniec 2012, 125 (= PL 177, 33): „,corvus ad archam non rediit, quia forsan [PL: forsitan] aquis diluvii interceptus periit, vel cadaveribus inventis forsitan supersedit".

${ }^{162}$ Por. Green, Latin Epics of the New Testament, s. 235; Springer, The Gospel as Epic in Late Antiquity, s. 13.

${ }^{163}$ Por. Malsbary, Epic Exegesis and the Use of Vergil, s. 66.

${ }^{164}$ Por. M. Zawada, Niewyczerpana historia ognistego proroka. Cykl Eliasza i Elizeusza w komentarzu duchowo-mistycznym, Poznań 2010, 53.

${ }^{165}$ Podobnie Hilarius Pictaviensis, Tractatus super Ps. 146, 12, PL 9, 874.

${ }^{166}$ Por. Szczepanowicz - Mrozek, Atlas zwierząt biblijnych, s. 164-165.

${ }^{167}$ Por. Sedulius, Hymnus 1, 11-12, Wójtowicz, s. 224: „Transitus ille monet, quid prima omisit origo: / Quid ventura patent, transitus ille monet”. Zob. Wójtowicz, Elegia Seduliusza, s. 103.

${ }_{168}$ Por. tenże, Paschale carmen I 148-151, Wójtowicz, s. 98.

${ }^{169} \mathrm{~W}$ trzech spośród czterech wersów poeta posługuje się przerzutniami i homoioteleutonami; wers 149 ozdabia hyperbatonem, który tworzą wyrazy o identycznych zakończeniach. Relację 
rozpoczyna od swoistej praeteritio. Zadając pytanie retoryczne: Quid referam $[\ldots]$ ? $^{170}$, głośno zastanawia się, po cóż miałby po raz kolejny opowiadać o tym znanym wydarzeniu historii biblijnej, po czym podejmuje się jego omówienia. Całkowicie pomija okoliczności, w których do niego doszło: skwar pustyni, szemrania ludu, modlitwę Mojżesza, czas pojawienia się manny oraz warunki jej zbierania, ustalone przez Boga (por. Wj 16, 1-36). Nagromadzenie licznych synonimów pozwala stwierdzić, iż wzrok poety skupia się na thumach (innumeras catervas, populum), jakie otrzymują pokarm (pane, cibos, dapes, escas) z nieba, które zwykło darzyć ludzkość deszczem, a nie chlebem (caelesti, nimbisque, in pluviis, in imbribus), a jest to pokarm niezwykle rozkoszny w smaku (seria dulcedine), pokarm godny nie śmiertelników, lecz niebiańskich zastępów (angelicos, superni nectaris) ${ }^{171}$. Nie mniej cudowny sposób dostarczenia pokarmu Bóg wybrał w trosce o Eliasza. Prorokowi usługiwały chciwe, drapieżne kruki ${ }^{172}$.

Eliasz i Henoch zajmują w ukazującej starotestamentalne cuda części Paschale carmen wyjątkowe miejsce. Pierwszemu z nich Seduliusz poświęca - jak już zostało powiedziane - najdłuższą, 17-wersową relację. O Henochu opowiada w czterech wersach, ale na samym początku analizowanego przez nas fragmentu poematu ${ }^{173}$. Powodem takiego postępowania poety może być, niewątpliwie, nieśmiertelność obu bohaterów. Seduliusz zauważa, iż los Henocha zdumiewa nawet przyrodę i śmierć. Przyroda straciła rachubę lat sprawiedliwego męża (natura perdente modum ${ }^{174}$ ), gdyż jako pierwszy człowiek od początku świata przeżył on wyjątkowo dhugie życie, które poeta opisuje za pomocą pleonazmu: multa per innumeros iam saecula contigit annos ${ }^{175}$. Natomiast śmierć, którą poeta personifikuje, widząc męża Bożego, który został wydarty (ademptum) jej, wydzierającej ludzi ze świata żywych, nie może wyjść z podziwu ${ }^{176}$. Jego głębię Seduliusz podkreśla stosując aliterację mors miratur ${ }^{177}$.

zamyka złoty wers; por. Sedulius, Paschale carmen I 148-151, Wójtowicz, s. 98: „Quid referam innumeras caelesti pane catervas / Angelicos sumpsisse cibos, nimbisque superni / Nectaris seria populum dulcedine pastum / In pluviis habuisse dapes et in imbribus escas?".

${ }^{170}$ Por. Sedulius, Paschale carmen I 148, Wójtowicz, s. 98.

${ }^{171}$ Por. tamże I 148-151, Wójtowicz, s. 100.

172 Tamże I 170-173, Wójtowicz, s. 100.

${ }^{173}$ Por. tamże I 103-106, Wójtowicz, s. 94.

${ }_{174}$ Tamże I 105, Wójtowicz, s. 94.

175 Tamże I 104, Wójtowicz, s. 94.

${ }^{176}$ Por. Terentius, Andria 697, ed. J. Sargeaunt, London - Cambridge 1953, 74: „hanc nisi mors mi adimet nemo"; Horatius, Carmina II 4, 10, ed. O. Keller, Wien 1907, 34: „et ademptus [scil. mortuus] Hector".

177 Sedulius, Paschale carmen I 106, Wójtowicz, s. 94. W tymże wersie znajdujemy jeszcze jedną aliterację, ponadto został on ozdobiony homoioteleutonem. Por. tamże I 105, Wójtowicz, s. 94: „Terra tulit genitum, sed mors miratur ademptum”. 
$\mathrm{Na}$ relację ${ }^{178}$ o ognistym proroku ${ }^{179}$ składają się:

- Opowieść o cudownym żywieniu Eliasza przez kruki, połączona z mającym charakter dygresji opowiadaniem o charakterze kruka oraz jego zachowaniu w czasie potopu ${ }^{180}$.

- Bardzo ogólnikowe zakreślenie sylwetki moralnej proroka i przebiegu jego życia: był pełen Boga, dokonał licznych cudów, przed odejściem ze świata uczynił przyjaciela dziedzicem swej mocy i godnym swych wielkich dzieł następcą ${ }^{181}$.

- Opis cudownego uniesienia Eliasza do nieba: u kresu ziemskiego życia prorok został uniesiony do nieba ${ }^{182}$. Natchniony autor mówi o ognistym powozie, zaprzężonym w ogniste rumaki, na którym Eliasz wśród wichru wstąpił do niebios (por. $2 \mathrm{Krl} 2,11$ ). Seduliusz rozbudowuje opis niezwykłego zdarzenia, dodając mu blasku, poszerzając przestrzeń, w której się rozgrywa, a także wskazując cel wędrówki proroka, o którym Pismo Święte milczy. W jego relacji lśnią złote gwiazdy, wyścielające jaśniejącą drogę, którą przemierza mknący jak ognista błyskawica powóz, zanurzony w płonących płomieniach rydwan proroka. Należy zwrócić uwagę na to, iż owo lśnienie wręcz oślepia czytelnika dzięki nagromadzonym przez poetę licznym aliteracjom: Aurea flammigeris evectus astra quadrigis / [...] sidereum penetravit iter curruque $\underline{\text { corusco }}^{183}$. Eliasz podąża do krainy wiecznej szczęśliwości, przemierzając ogromne przestworza (spatio maiore ${ }^{184}$ ) po drogach, na których lekki bieg kół nie kreśli bruzd: Qua levis aerios non exprimit orbita sulcos ${ }^{185}$.

Jak wiadomo, jednym z dowodów na znaczący wpływ, jaki wywarła na kulturę antyczną agonistyka, stanowi fakt, iż wielu starożytnych, także chrześcijańskich autorów, chętnie posługiwało się jej obrazowym językiem ${ }^{186}$. Przekonujemy się o tym również czytając analizowany fragment Paschale carmen. Seduliusz postrzega Eliasza jako okrytego chwałą zwycięzcę, gdyż relacjonując jego życie stosuje słownictwo związane z wyścigami rydwanów. Mówi mianowicie, iż biblijny bohater ominął metę, do której zmierza każdy człowiek w swej ziemskiej wędrówce: humani metam non contigit aevi ${ }^{187}$. Mety, to jest stożkowate słupy o ostrym zakończeniu, znajdowały się na końcach okrążanego przez wyścigowe tory muru, umiejscowionego centralnie w obrębie wydłu-

\footnotetext{
${ }^{178}$ Por. tamże I 170-187, Wójtowicz, s. 100.

${ }^{179}$ Przyjmuję określenie M. Zawady (Niewyczerpana historia ognistego proroka, s. 53).

${ }^{180}$ Por. Sedulius, Paschale carmen I 170-175, Wójtowicz, s. 100.

${ }^{181}$ Por. tamże I 176-178, Wójtowicz, s. 100.

${ }^{182}$ Por. tamże I 178-183, Wójtowicz, s. 100.

${ }^{183}$ Por. tamże I 179 i 181, Wójtowicz, s. 100. Inne zastosowane przez Seduliusza aliteracje por. tamże I 127, 132, 139, 160, 181 i 189.

${ }^{184}$ Por. tamże I 182, Wójtowicz, s. 100.

${ }^{185}$ Por. tamże I 180, Wójtowicz, s. 100.

${ }^{186}$ Por. T. Gacia, Metaforyka agonistyczna w literaturze tacińskiej chrześcijańskiego antyku, Kielce 2007, 30-38 i 46-55.

${ }^{187}$ Sedulius, Paschale carmen I 183, Wójtowicz, s. 100.
} 
żonego cyrku (spina). Zbliżenie się do mety stanowiło najbardziej ekscytujący dla widzów i krytyczny dla jeźdźców moment gonitwy. Kwadrygi okrążały spinę, przy czym szczególnej zręczności wymagało takie ominięcie mety, by przejechać jak najbliżej niej (w celu skrócenia drogi), ale jej nie dotknąć, gdyż zderzenie ze słupem powodowało katastrofę ${ }^{188}$. Pisząc o Eliaszu, Seduliusz postrzega ludzką egzystencję jako jazdę na rydwanie, przy czym ziemskie życie stanowi tę jej część, która dobiega końca na zakręcie, gdzie przez śmierć - swego rodzaju punkt nawrotu - przechodzimy na następne okrążenie, do życia wiecznego. Eliaszowi udało się zatem nie dotknąć mety, a więc pominąć śmierć, przejść z życia do życia. Poza tym autor poematu ukazuje ognistego proroka jako wodza, który odniósł wspaniałe zwycięstwo nad grzechem i śmiercią i triumfował: triumphum / duxit ${ }^{189}$, a więc dostąpił najwyższego wojskowego wyróżnienia znanego rzymskiemu czytelnikowi, niejako wjeżdżając do nieba na wozie triumfatora (currus triumphalis), by złożyć hołd Bogu ${ }^{190}$. Ostatni w historii Rzymu triumf, obchodzony zgodnie z zasadami ustalonymi przez ponadtysiącletnią tradycję, celebrował w roku 303 cesarz Dioklecjan ${ }^{191}$. Mimo to współcześni poety prawdopodobnie zgodziliby się ze Scypionem, mówiącym, iż nie było w Rzymie nic bardziej okazałego niż triumf ${ }^{192}$; wyścigi rydwanów przez wieki pozostawały ulubioną rozrywką rzymskiego świata ${ }^{193}$. Zauważmy, iż odwołując się do dobrze znanych, bliskich rzymskiemu czytelnikowi dziedzin życia Seduliusz jawi się jako prawdziwy budowniczy mostów pomiędzy światem Biblii a światem grecko-rzymskim.

- Pozytywna ocena relacjonowanego wydarzenia oraz jej uzasadnienie z odwołaniem się do etymologii imienia poety ${ }^{194}$. Seduliusz wkracza do relacjonowanych wydarzeń, z mocą - posługując się eksklamacją ${ }^{195}$ - wyrażając przekonanie, iż przebycie błyszczącej drogi pełnego gromów nieba (fulminei praelucens semita caeli ${ }^{196}$ ) słusznie przypadło w udziale Eliaszowi. Podsumowując opis uniesienia i zamykając relację o proroku, poeta znów przenosi czytelnika w semantyczne pole blasku, lśnienia, jasności. Stwierdza, iż Eliasz

${ }^{188}$ Por. D. Słapek, Sport i widowiska w świecie antycznym, Warszawa 2010, 745-749; L. Winniczuk, Ludzie, zwyczaje i obyczaje starożytnej Grecji i Rzymu, Warszawa 2006, 558-559; М. Сергеенко, Простыле люди древней Италии, Москва 1964, 143-147.

${ }^{189}$ Sedulius, Paschale carmen I 182-183, Wójtowicz, s. 100.

${ }^{190}$ Por. K. Balbuza, Triumfator. Triumf $i$ ideologia zwycięstwa $w$ starożytnym Rzymie epoki Cesarstwa, Poznań 2005, 30-68.

${ }^{191}$ Por. tamże, s. 167-169.

${ }^{192}$ Por. Titus Livius, Ab urbe condita XXX 15, 12, ed. F. Fügner, Leipzig 1926, 218: „Neque magnificentius quicquam triumpho apud Romanos [...] esse".

${ }^{193}$ Por. М. Сергеенко, Жизнь древнего Рима, Санкт-Петербург 2000, 231-239.

${ }^{194}$ Por. Sedulius, Paschale carmen I 184-187, Wójtowicz, s. 100.

195 Por. tamże I 184-185, Wójtowicz, s. 100. W odróżnieniu od H. Wójtowicza (Apostrofa w I księdze „Paschale carmen” Seduliusza, „Classica Wratislaviensia” 20:1996, 132) nie dostrzegam w tym fragmencie apostrofy do niebieskiej ścieżki, którą przemierza Eliasz.

${ }^{196}$ Sedulius, Paschale carmen I 184, Wójtowicz, s. 100. 
był godny takiego wyróżnienia: lśnił swymi zasługami i imieniem, które po grecku, o ile zmienimy w nim jedną literę, oznaczać będzie słońce ${ }^{197}$. Zauważmy, iż w ostatnich wersach poświęconych prorokowi Seduliusz jawi się jako prawdziwy poeta doctus. Opisuje charakter bohatera poprzez wyjaśnienie znaczenia jego imienia, a także posługuje się używaną przez rzymskich poetów zlatynizowaną nazwą Greków walczących pod Troją - Achajowie, gdy mówi o greckim imieniu Eliasza sermo Achivus ${ }^{198}$.

5. Cud jako metamorfoza. Dwa spośród opisywanych przez Seduliusza cudów stanowią w swej istocie cudowne przemiany: żona Lota zmienia się w słup soli, a laska Aarona - w węża. Jak już zauważyłam, relacjonując pierwsze spośród wspomnianych wydarzeń, Seduliusz poprzestaje na jego odnotowaniu (dwa wersy z sześciu) oraz skupia się głównie na wyjaśnieniu znaczenia tej Bożej ingerencji (trzy i pół wersu). Również rekapitulując opis wszystkich prezentowanych $\mathrm{w}$ poemacie starotestamentalnych cudów, o żonie Lota pisze jedynie: muliebres transtulit [scil. Deus] artus / in simulacra salis ${ }^{199}$. Zupełnie inaczej traktuje drugą przemianę. Podczas gdy biblijny autor wspomina, że Aaron na polecenie Boga rzucił laskę, po czym zamieniła się ona w węża, ów zaś pożarł węże, które powstały z lasek egipskich czarowników, Seduliusz skupia się na przebiegu metamorfozy oraz informuje czytelnika o dalszych losach węża, który znów staje się laską ${ }^{200}$. Opis przemiany jest bardzo plastyczny i oparty na antytetycznym podłożu (łagodność i spokój, sztywność laski - srogość, zwinność żmii). Otwierająca i właściwie streszczająca cały opis antyteza jest dodatkowo wzmocniona poprzez zastosowanie wyrazów o podobnym brzmieniu; jeden $\mathrm{z}$ nich stanowi ponadto element połączonego z homoioteleutonem hyperbatonu. Oto spokojna laska ożywa i zmienia się w okrutnego węża: Mitis in inmitem virga est animata dragonem ${ }^{201}$. Na oczach zdumionego czytelnika zmienia się ona w kłęby, z których każdy, jak zauważa poeta, przebywa w ciągłym ruchu, zwija się i wygina niczym łuk (per flexos sinuata globos ${ }^{202}$ ); butnie unosi wydymającą się, pokrytą łuską szyję (squamea colla tumens ${ }^{203}$ ). Zaznaczmy, iż autor jest bardzo oszczędny w słowach: posługuje się niewielu, acz bardzo trafnie dobranymi wyrazami, które dzięki swej

${ }^{197}$ Por. tamże I 184-187, Wójtowicz, s. 100: „Quam bene fulminei praelucens semita caeli / Convenit Heliae! meritoque et nomine fulgens / Hac ope dignus erat: nam si sermonis Achivi / Una per accentum mutetur littera, sol est”. Zmiana, o której mówi poeta, dotyczy litery $\alpha$. Po jej

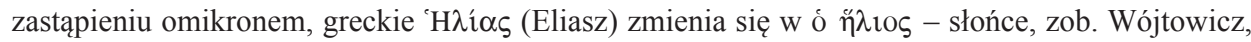
Komentarz, w Sedulius Caelius, Opera omnia, s. 101, nota 59.

${ }^{198}$ Por. Sedulius, Paschale carmen I 186, Wójtowicz, s. 100. Zob. Wójtowicz, Komentarz, s. 101 , nota 58.

${ }^{199}$ Sedulius, Paschale carmen I 224-225, Wójtowicz, s. 104.

${ }^{200}$ Por. tamże I 132-135, Wójtowicz, s. 96; Wj 7, 8-13.

${ }^{201}$ Por. tamże I 132, Wójtowicz, s. 96.

${ }^{202}$ Por. tamże I 133, Wójtowicz, s. 96.

${ }^{203}$ Por. tamże I 134, Wójtowicz, s. 96. 
wieloznaczności oddają właśnie to, co chce on powiedzieć, a każde z nich doskonale pasuje do kontekstu. Użyty przez niego w formie participium praesentis activi czasownik tumere oznacza bowiem zarówno wydymanie się, jak też wzbijanie się w górę, wzburzenie i unoszenie się pychą ${ }^{204}$. Stosując zapewniającą wypowiedzi zwięzłość składnię ablativus qualitatis, Seduliusz mówi, iż wąż z Księgi Wyjścia - niczym błyszczący na słońcu wąż, do którego Wergiliusz porównuje lśniącą zbroję Pyrrusa - ma języki rozszczepione na trzy części: linguisque trisulcis ${ }^{205}$. Tymczasem czytający te słowa odbiorca widzi drgający ruch pełnych jadu języków i słyszy towarzyszące mu pełne groźby syczenie gada. Wąż pożera pełne wrogości wobec niego jadowite żmije i na powrót staje się zwykłą gałęzią, przybierając właściwą gałęziom twardość i sztywnośćc ${ }^{206}$. Zauważmy, iż owa podwójna - nieznana nawet mistrzowi opisów przemian Owidiuszowi - metamorfoza zachodzi błyskawicznie, co podkreśla użycie przez poetę aż trzech imiesłowów obok trzech form osobowych: est animata, flexos, sinuata, tumens, sorbuit, redit. Niezwykłość, wręcz bajeczność opisywanego wydarzenia potęguje zastosowanie na określenie węża wyrazu draco, który oznacza baśniowego potwora, smoka ${ }^{207}$. Poetyckiego zabarwienia relacji dodaje użyty w znaczeniu ,zamienić rzecz w żywą istotę” czasownik animare ${ }^{208}$, który kompetentny czytelnik kojarzy z opisanymi przez Nazona kroplami krwi Meduzy Gorgony. Spadając na ziemię, zamieniały się one właśnie $\mathrm{w}$ żmije ${ }^{209}$. O jadowitej odmianie wężów zwanych chelydri wspominają zarówno poeci ${ }^{210}$, jak również autorzy pism medycznych, którzy opisują antidota stosowane w przypadku ich ukąszeń.

6. Cud jako paradoks. Cud jest wydarzeniem, które wykracza poza znany człowiekowi porządek rzeczy, i jako takie podważa ludzkie doświadczenie, zaprzecza zdrowemu rozsądkowi, zaskakuje, przynosi nieoczekiwaną prawdę o rzeczywistości, dowodzi, iż poza materialnym światem, który poznajemy w pierwszej kolejności zmysłami, składa się na nią również niewidzialny wymiar duchowy. Cudowne ingerencje Boże w odczuciu autora poematu najwy-

${ }^{204}$ Por. Plezia V 455, s.v. tumeo.

${ }^{205}$ Sedulius, Paschale carmen I 133, Wójtowicz, s. 96. Por. Vergilius, Aeneis II 471-475, ed. Pichon, s. 306. Historycy literatury są zgodni co do tego, iż spośród wszystkich łacińskich epików właśnie Wergiliusz wywarł najbardziej znaczący wpływ na Seduliusza; zob. Green, Latin Epics of the New Testament, s. 209; Wójtowicz, Wstęp, s. 52. Na uwagę zasługuje poświęcony temu zagadnieniu artykuł H. Wójtowicza (Seduliańska sztuka imitacji Wergiliusza, w: Orbis antiquus, s. 39-43).

${ }^{206}$ Por. Sedulius, Paschale carmen I 134-135, Wójtowicz, s. 96: ,inimicos ore chelydros / Sorbuit et proprii redit in virgulta rigoris".

${ }^{207}$ Por. Plezia II 250-251, s.v. draco.

${ }^{208}$ Por. tamże I 198, s.v. animo.

${ }^{209}$ Por. Ovidius, Metamorphoses IV 618-619, ed. Merkel, s. 83: „Gorgonei capitis guttae cecidere cruentae, / Quas humus exceptas varios animavit in angues".

${ }^{210}$ Por. Vergilius, Georgica III 415, ed. Pichon, s. 192; Ovidius, Metamorphoses VII 272, ed. Merkel, s. 134; Celsus, De medicina V 27, 8, ed. Daremberg, s. 255. 
raźniej mają wymiar paradoksalny. Roger Green słusznie nazywa Seduliusza poetą paradoksów ${ }^{211}$. W paradoksy obfituje analizowany fragment poematu. Z pięciu paradoksów w całości utkany jest opis płonącego krzewu, w którym objawił się Mojżeszowi Jahwe. Gorzał, ale płomienie nie wyrządzały mu szkody (ignibus innocuis flagrans ${ }^{212}$ ); płonął, nie płonąc (non ardens, arde$r e^{213}$ ); drewno nie dostarczało pożywienia ogarniającemu je żarowi (nec iuncta calori / materies alimenta dabat ${ }^{214}$ ); był żywy, nie ulegał wysuszeniu ani spieczeniu (nec torrida vivens / sensit damna ${ }^{215}$ ); pełne przyjaznego skwaru płomienie czule lizały okryte zielenią gałęzie (amici fomitis aestu / frondea blanditiae lambebant robora flammae ${ }^{216}$ ). Izraelici przeszli przez morze pozbawione morza (absentis pelagi mare ${ }^{217}$ ). Ieiuna marmora - a więc będące na czczo kamienie - vomuerunt - wyrzuciły z siebie, niejako zwymiotowały niesłychanym dotąd, ożywczym napojem - novum potum ${ }^{218}$. Kruk, który skalał siebie występkiem na wodach potopu, obmył swe przewiny na lądzie, gdy na rozkaz Boży przyszedł z pomocą Eliaszowi: abluit in terris quidquid deliquit in undis ${ }^{219}$. Czego może spodziewać się człowiek, który spada z okrętu i zostaje połknięty przez wieloryba? Myśląc po ludzku, powinien wzbudzić akt doskonałej skruchy oraz żegnać się ze światem. Jednak Bóg myśli inaczej niż człowiek. Zanurzony w morzu Jonasz nawet nie poczuł wody: in pelago non sensit aquas ${ }^{220}$. Jahwe umieścił go w zapewniającym życie grobowcu, o czym Seduliusz mówi posługując się dającym efekt paradoksu oksymoronem - vitale sepulchrum ${ }^{221}$. Stał się nim brzuch morskiego potwora, w którym - zauważmy - prorok był paradoksalnie bardziej bezpieczny (tutusque in ventre ferino $^{222}$ ), niż podróżujący najlepszym statkiem.

Człowiek, który przyjmuje Boga, staje się zdolny do szalonych, niezrozumiałych pozostałym śmiertelnikom, a więc paradoksalnych zachowań. Gotowy złożyć w ofierze syna Bogu, który mu tego syna dał, Abraham odrzucił precz miłość, by wykazać się większą miłością: pietate remota / plus pietatis habens $^{223}$. Gdy trzej młodzieńcy, którzy woleli umrzeć niż sprzeniewierzyć się

\footnotetext{
${ }^{211}$ Por. Green, Latin Epics of the New Testament, s. 165.

${ }^{212}$ Sedulius, Paschale carmen I 127, Wójtowicz, s. 96.

${ }^{213}$ Tamże I 128, Wójtowicz, s. 96.

${ }^{214}$ Tamże I 128-129, Wójtowicz, s. 96.

${ }^{215}$ Tamże I 129-130, Wójtowicz, s. 96.

216 Tamże I 130-131, Wójtowicz, s. 96.

${ }^{217}$ Tamże I 139, Wójtowicz, s. 98.

${ }^{218}$ Tamże I 157, Wójtowicz, s. 98. Zauważmy, iż to dość niezwykłe sformułowanie powstało być może pod wpływem lektury Ambrożego (De Elia et ieiunio V 15, PL 14, 737: „Petra aquam vomuit"; VII 21, PL 14, 738: ,ieiunium petram solvit in fontes aquarum”).

${ }^{219}$ Sedulius, Paschale carmen I 175, Wójtowicz, s. 100.

${ }^{220}$ Tamże I 193, Wójtowicz, s. 102.

${ }^{221}$ Tamże.

${ }^{222}$ Tamże I 194, Wójtowicz, s. 102.

${ }^{223}$ Tamże I 116-117, Wójtowicz, s. 94.
} 
Panu, zostali wepchnięci w sam środek pieca (medios truduntur in ignes ${ }^{224}$ ), stos nie śmiał płonąć (nil audente rogo ${ }^{225}$ ), i trawił ich jedynie serdeczny żar (tantumque ardore calentes / cordis ${ }^{226}$ ), uzdalniający ich do pokonania pożaru ułudnej kaźni (imagineae vincunt incendia poenae ${ }^{227}$ ) ogniem ducha (igne animi $^{228}$ ). Zachwycony postawą dzielnych młodzianów, w których chrześcijanie pierwszych wieków widzieli symbol męczenników ${ }^{229}$, poeta woła: o quanta est credentium gloria! ${ }^{230}$ i podsumowuje opowiedzianą niejako jednym tchem - o czym świadczą liczne przerzutnie (7 w 9 wersach) - historię mającym paradoksalne zabarwienie stwierdzeniem, iż płomień pieca zgasł ugaszony płomieniami ich gorącej wiary: flammis / ardentis fidei restincta est flamma camini $^{231}$. Zauważmy, iż dzięki stosowanym eksklamacjom poeta wkracza w relacjonowane przezeń odległe w czasie cudowne wydarzenia, przybliża je odbiorcy i każe również jemu ustosunkować się do nich, osobiście je przeżyćc ${ }^{232}$.

$* * *$

Marian Rusecki stwierdza, iż autorów wczesnochrześcijańskich interesowała nie relacja cudów do sił natury, ale ich miejsce w zbawczym planie Boga; to, że dzieją się w zależności od Jego woli, według Jego odwiecznego przewidzenia i postanowienia, realizują historię zbawienia i przybliżają jej pełnię - przyjście na świat Syna Bożego, wychowując ludzkość i przygotowując na Jego przyjście ${ }^{233}$. Stwierdzenie to również w przypadku autora Paschale carmen jest prawdziwe, choć - moim zdaniem - jedynie po części. Cuda fascynują Seduliusza jako wydarzenia niezwykłe same w sobie, a zarazem prowadzące do poznania jeszcze bardziej niezwykłej rzeczywistości boskiej ekonomii zbawienia, którą urzeczywistniają. Dobitnie tego dowodzi, dokonując podsumowania osiemnastu starotestamentalnych cudów, o których opowiada w swoim poemacie. Rekapitulację rozpoczyna niezwykle podniosła, zawierająca pełne patosu pytanie retoryczne apostrofa do natury: Dic ubi

${ }^{224}$ Tamże I 201, Wójtowicz, s. 102.

${ }^{225}$ Tamże I 202, Wójtowicz, s. 102.

${ }^{226}$ Tamże I 202-203, Wójtowicz, s. 102.

${ }^{227}$ Tamże I 203, Wójtowicz, s. 102.

${ }^{228}$ Tamże I 204, Wójtowicz, s. 102.

${ }^{229}$ Por. Forstner, Świat symboliki chrześcijańskiej, s. 315.

${ }^{230}$ Tamże I 204, Wójtowicz, s. 102. W analizowanym fragmencie Seduliusz posługuje się eksklamacjami jeszcze dwa razy, aby wyrazić zachwyt postawą Abrahama (w. 116, Wójtowicz, s. 94) oraz wspaniałym zakończeniem ziemskich dni Eliasza (w. 185, Wójtowicz, s. 100).

${ }^{231}$ Tamże I 204-205, Wójtowicz, s. 102.

${ }^{232}$ Zwraca na to uwagę również M. Roberts (The Jeweled Style. Poetry and Poetics in Late Antiquity, Ithaca 1989, 142).

${ }^{233}$ Por. M. Rusecki, Traktat o cudzie, Lublin 2006, 24-35. 
sunt, natura, tuae post talia leges, / Qui totiens tibi iura tulit? ${ }^{234}$. A więc cud to przede wszystkim wydarzenie, które wykracza poza naturę i unieważnia jej prawa. Fascynując ludzi - zwłaszcza ludzi wrażliwych, a takimi są poeci w ogóle i nasz poeta w szczególności - cud kieruje ich umysły i serca ku swemu Sprawcy. Dokonując cudów Bóg pozwala ludzkości poznać swą potęgę, opatrzność, miłosierdzie; wychowuje ją i przygotowuje na przyjęcie Chrystusa; przepowiada ostateczne odkupienie kosmosu na końcu czasów. Opowiadając o starotestamentalnych cudach, poeta dąży do przekazania poganom i chrześcijanom nauki objawionej, jak również do wzbudzenia w czytelnikach zachwytu, wdzięczności, miłości i zaufania wobec Trójcy.

Błyskawicznie streszczając w zaledwie 16 wersach cudowne wydarzenia opisane uprzednio w 116 wersach $^{235}$, Seduliusz posługuje się osiemnastoma czasownikami w formie trzeciej osoby liczby pojedynczej, by podkreślić, że za każdym z cudów stoi Bóg ${ }^{236}$. To Jemu, Stworzycielowi i Władcy świata, służy wszystko, co istnieje; Jemu dedykuje swą pieśń poeta ${ }^{237}$. Głoszenie wielkich Bożych dzieł, którego podejmuje się Seduliusz, nie ma służyć zaspokojeniu czczej ciekawości, ale budzić wiarę i prowadzić do Jego uwielbienia ludzkość, z którą On poprzez cudowne znaki usiłuje nawiązać kontakt, aby ją zbawić.

\section{OLD TESTAMENTAL MIRACLES IN PASCHALE CARMEN BY SEDULIUS}

\section{(Summary)}

Before turning to the wonderful Saviour's deeds, that he strives to praise in Paschale Carmen, Sedulius introduces his reader into the old testamental history of salvation. In the Book 1, which fulfils the functions of a preface to the poem, he recounts 18 miracles that took place before Christ was born, since the ages of the Patriarchs to the period of the Babylonian captivity. These relations appear to be separate, self-contained stories. The longest is devoted to the miraculous fate of the prophet Elijah (lines 170-187); in the shortest the poet tells about the Balaam's donkey, an animal without speech, who spoke to its master with a human voice (lines 160-162). Miracles fascinate Sedulius as extraordinary events, which deny

${ }^{234}$ Sedulius, Paschale carmen I 220-221, Wójtowicz, s. 104. W podobnych słowach poeta zwraca się do śmierci, pokonanej przez umierającego na krzyżu Chrystusa, tamże V 276-277, Wójtowicz, s. 208: „Dic ubi nunc tristis victoria, dic ubi nunc sit / Mors stimulus horrenda tuus”; zob. Wójtowicz, Apostrofa, s. 132-133.

${ }^{235}$ R. Green (Latin Epics of the New Testament, s. 169) nazywa ten fragment „,rapid-fire survey”.

${ }^{236}$ Por. Sedulius, Paschale carmen I 221-237, Wójtowicz, s. 104-106: 221: iussit; 223: fecundavit, praecepit; 224: transtulit; 226: dedit, solvit; 227: siccavit; 228: pluit, produxit; 229: coegit; 230: distulit; 231: dedit; 232: transvexit; 233: adiecit; 234: fundavit; 235: servavit; 236: pavit; 237: iussit.

${ }^{237}$ Por. tamże I 238-241, Wójtowicz, s. 106: „Nempe creatori, cuius quaecumque videntur / Seu quaecumque latent et rerum machina sermo est, / Omne suum famulatur opus sequiturque iubentis / Imperium quacumque trahit sententia nutu". 
the laws of nature and contradict common sense. At that they are sometimes connected with a marvelous metamorphosis. God performs miracles in order to show to the mankind His might, providence and kindness; to educate human beings and to prepare them for the coming of Christ; to foretell cosmic redemption at the end of times. Telling about the old testamental miracles Sedulius tends to refer both to the unbelievers and to the believers the revealed truth. He also aims to awake in the readers' hearts wonderment, gratitude, love and trust towards the Holy Trinity.

Key words: Sedulius, miracle, Bible, metamorphosis, paradox, Elijah, prefiguration, cosmic redemption, Divine Mercy.

Słowa kluczowe: Seduliusz, cud, Biblia, metamorfoza, paradoks, Eliasz, prefiguracja, odkupienie kosmosu, Miłosierdzie Boże. 